This Health Hazard Evaluation (HHE) report and any recommendations made herein are for the specific facility evaluated and may not be universally applicable. Any recommendations made are not to be considered as final statements of NIOSH policy or of any agency or individual involved. Additional HHE reports are available at http://www.cdc.gov/niosh/hhe/

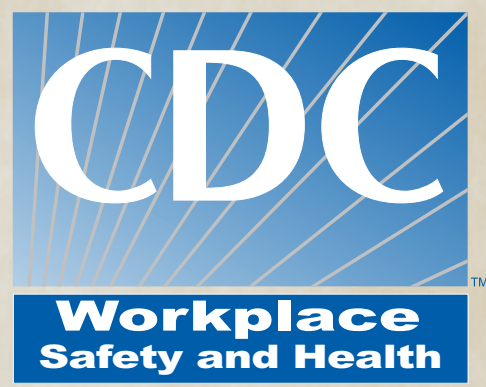

\title{
Evaluation of Electromagnetic Field Exposures at a Research Institution's Laboratories and Atomic Time Radio Stations - Colorado
}

Kenneth W. Fent, PhD

David Conover, PhD

Health Hazard Evaluation Report

HETA 2009-0171-3119

March 2011

DEPARTMENT OF HEALTH AND HUMAN SERVICES

Centers for Disease Control and Prevention

National Institute for Occupational
Safety and Health 
The employer shall post a copy of this report for a period of 30 calendar days at or near the workplace(s) of affected employees. The employer shall take steps to insure that the posted determinations are not altered, defaced, or covered by other material during such period. [37 FR 23640, November 7, 1972, as amended at 45 FR 2653, January 14, 1980]. 


\section{CONTENTS}

\section{REPORT}

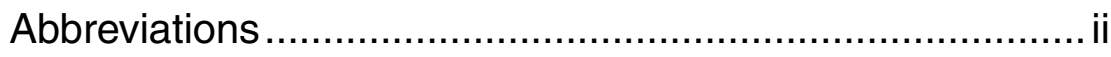

Highlights of the NIOSH Health Hazard Evaluation............. iii

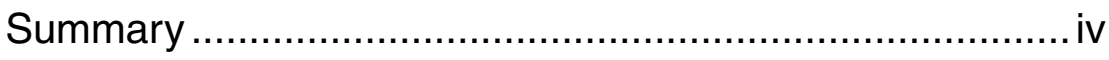

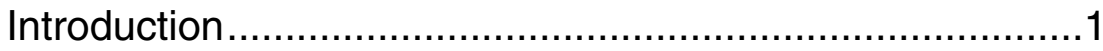

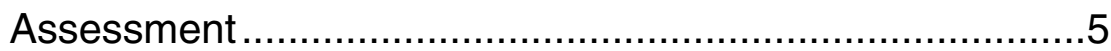

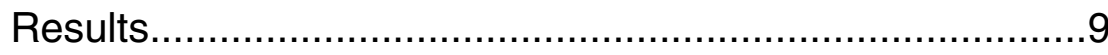

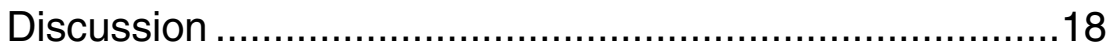

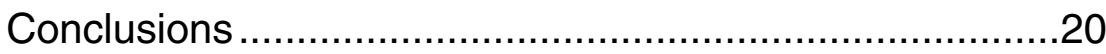

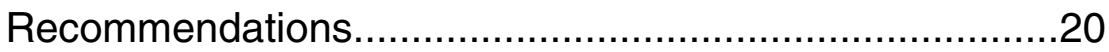

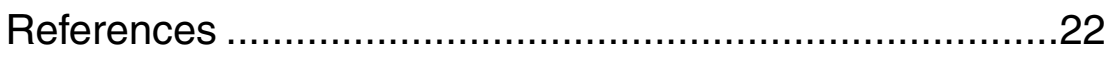

APPENDIX A Occupational Exposure Limits and Health Effects.............23

APPENDIX B E-field Strengths Measured at the Atomic Time Radio

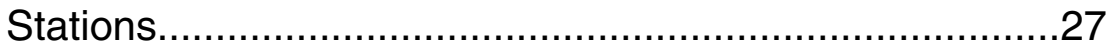

APPENDIX C H-field Strengths Measured at the Atomic Time Radio

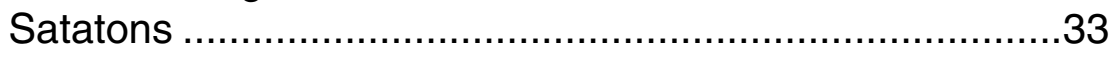

ACKNOWLEDGMENTS

Acknowledgments and Availability of Report. 


\begin{tabular}{|c|c|}
\hline$\sim$ & $\begin{array}{l}\text { Approximately } \\
\text { Amps per meter }\end{array}$ \\
\hline ACGIH® & American Conference of Governmental Industrial Hygienists \\
\hline B-field & Magnetic flux density \\
\hline CFR & Code of Federal Regulations \\
\hline DNR & Did not record \\
\hline E-field & Electric field \\
\hline EMF & Electromagnetic field \\
\hline FCC & Federal Communications Commission \\
\hline $\mathrm{GHz}$ & Gigahertz \\
\hline GPS & Global Positioning System \\
\hline $\mathrm{HF}$ & High frequency $(3-30 \mathrm{MHz})$ \\
\hline H-field & Magnetic field \\
\hline ICNIRP & International Commission on Non-Ionizing Radiation Protection \\
\hline IEEE & Institute of Electrical and Electronics Engineers \\
\hline $\mathrm{kHz}$ & Kilohertz \\
\hline $\mathrm{kW}$ & Kilowatts \\
\hline LF & Low frequency $(30-300 \mathrm{kHz})$ \\
\hline $\mathrm{MHz}$ & Megahertz \\
\hline MPE & Maximum permissible exposure \\
\hline $\mathrm{mT}$ & Millitesla \\
\hline NA & Not applicable \\
\hline $\mathrm{NIOSH}$ & National Institute for Occupational Safety and Health \\
\hline OEL & Occupational exposure limit \\
\hline OSHA & Occupational Safety and Health Administration \\
\hline PEL & Permissible exposure limit \\
\hline REL & Recommended exposure limit \\
\hline RF & Radio frequency and microwave radiation $(30 \mathrm{kHz}$ to $300 \mathrm{GHz})$ \\
\hline RMS & Root-mean-square \\
\hline STEL & Short term exposure limit \\
\hline Sub-RF & Sub-radio frequency $(<30 \mathrm{kHz})$ \\
\hline TLV® & Threshold limit value \\
\hline TWA & Time-weighted average \\
\hline UHF & Ultra high frequency $(300 \mathrm{MHz}$ to $3 \mathrm{GHz})$ \\
\hline VHF & Very high frequency $(30-300 \mathrm{MHz})$ \\
\hline $\mathrm{V} / \mathrm{m}$ & Volts per meter \\
\hline WEEL & Workplace environmental exposure level \\
\hline $\mathrm{W} / \mathrm{m}^{2}$ & Watts per square meter \\
\hline
\end{tabular}




\section{HIGHLIGHTS OF THE NIOSH HEALTH Hazard Evaluation}

The National Institute for Occupational Safety and Health (NIOSH) received a request for a health hazard evaluation at a research institution in Colorado. Health and safety management submitted the request because of concern about possible radio frequency and microwave radiation (RF) and subRF electromagnetic field (EMF) exposures at the research institution's laboratories and atomic time radio stations.

\section{What NIOSH Did}

- We evaluated the facilities August 31-September 3, 2009. We returned to further evaluate the atomic time radio stations August 3-5, 2010.

- We measured static magnetic fields at the superconducting magnet laboratory and magnetic annealing laboratory.

- We measured RF field strengths at the interoperability communications laboratory and atomic time radio stations.

\section{What NIOSH Found}

- Static magnetic flux densities exceeded the occupational exposure limit (OEL) for medical device wearers working within 3 feet of the superconducting magnet.

- RF electric field strengths exceeded the most conservative OELs within 1 foot of the interoperability communications laboratory roof-mounted antennas.

- RF electric and magnetic field strengths exceeded the most conservative OELs within 30 feet of the 10- and 15-megahertz antennas at the atomic time radio stations.

- RF electric and magnetic field strengths exceeded action levels at locations along the access road circling the high frequency antennas at the atomic time radio stations.

- RF electric field strengths exceeded action levels within 700 feet of both helix houses at the atomic time radio stations.

\section{What Managers Can Do}

- Learn more about the potential hazards associated with EMF exposure.

- Start a comprehensive EMF safety program.

\section{What Employees Can Do}

- Learn about EMF radiation hazards and the use of warning signs and other controls to prevent overexposures to EMF radiation.

- Report health and safety concerns to your manager.

- Share ideas on ways to improve the EMF safety program with the EMF safety officer. 


\section{NIOSH evaluated EMF exposures at a research institution's laboratories and atomic time radio stations. We found sub- RF and RF field strengths above action levels and OELs. We recommend starting a comprehensive EMF safety program.}

In June 2009, NIOSH received a health hazard evaluation request from a research institution in Colorado. The request concerned sub-RF (below $30 \mathrm{kHz}$ ) and RF ( $30 \mathrm{kHz}$ to $300 \mathrm{GHz}$ ) EMF exposures at the institution's laboratories and atomic time radio stations. The radio stations were located at a remote site in Colorado separate from the laboratories. In response to this request, we evaluated the facilities on August 31-September 3, 2009, and August 3-5, 2010.

During the first evaluation, magnetic flux density (B) fields near or above OELs were measured in the magnetic annealing laboratory and superconducting magnet laboratory. Electric (E) field strengths above OELs were measured at the interoperability communications laboratory. Measurements taken at the atomic time radio stations demonstrated a potential for overexposure to RF. However, because the RF meter we used did not span all broadcasted frequencies and potentially perturbed fields, we planned another evaluation of the atomic time radio stations using appropriate instrumentation in 2010.

During this second evaluation, we measured $\mathrm{E}$ and magnetic $(\mathrm{H})$ field strengths at the atomic time radio stations. E-field strengths exceeded the action levels along the access roads leading to the helix houses within 700 feet of the LF north and south antennas. $\mathrm{E}$ - and $\mathrm{H}$-field strengths exceeded the action levels at locations along the access road circling the HF antennas. $\mathrm{E}$ - and $\mathrm{H}$-field strengths exceeded OELs within 30 feet of the 10 - and $15-\mathrm{MHz}$ antennas.

Because EMF field strengths exceeded OELs or action levels in some locations at the research institution, we recommended implementing a comprehensive EMF safety program. This program should be managed by an EMF safety officer. The EMF safety officer should maintain an inventory of EMF sources, conduct annual EMF safety awareness training, audit the EMF safety program annually, and install signage and other controls in areas where field strengths are likely to exceed OELs or action levels. In addition, a system should exist for employees to report EMF exposures incidents and provide feedback to the EMF safety officer.

Keywords: NAICS 541712 (Research and Development in the Physical, Engineering, and Life Sciences), Electromagnetic field, EMF, radio frequency, superconducting magnet, radio station, antenna 
In June 2009 NIOSH received a health hazard evaluation request from a research institution in Colorado. The request concerned potential EMF exposures at the institution's laboratories and atomic time radio stations. Although the research institution had a health and safety office, at the time of the request, it did not have a comprehensive EMF safety program. Two evaluations were conducted. The purpose of the evaluation on August 31-September 3, 2009, was to identify the primary sources of EMF radiation. The purpose of the evaluation on August 3-5, 2010, was to more thoroughly assess RF at the atomic time radio stations. Four primary EMF sources were identified. These sources are described below. All other sources we evaluated (building 24 antenna laboratory and time domain laboratory) had field strengths that were well below applicable OELs, so they are not described in this report.

\section{Magnetic Annealing Laboratory}

A magnetic thermal annealer for 3-inch wafers was contained inside a laboratory. The annealing chamber was an enclosed stainless steel vacuum chamber plumbed with argon gas. Anneals were completed in temperatures ranging from $100^{\circ} \mathrm{C}-600^{\circ} \mathrm{C}$. The magnet configuration produced a uniform 1 tesla magnetic field within the thermal annealer with weaker magnetic fields present outside the annealer.

\section{Superconducting Magnet Laboratory}

A superconducting magnet with a vertical room temperature bore was contained inside a laboratory (Figure 1). The maximum strength of the static magnetic field in the vertical center of the bore was 4.5 tesla. However, the center of the bore was inaccessible to employees. One employee worked inside the laboratory during our evaluation. 
INTRODUCTION (CONTINUED)

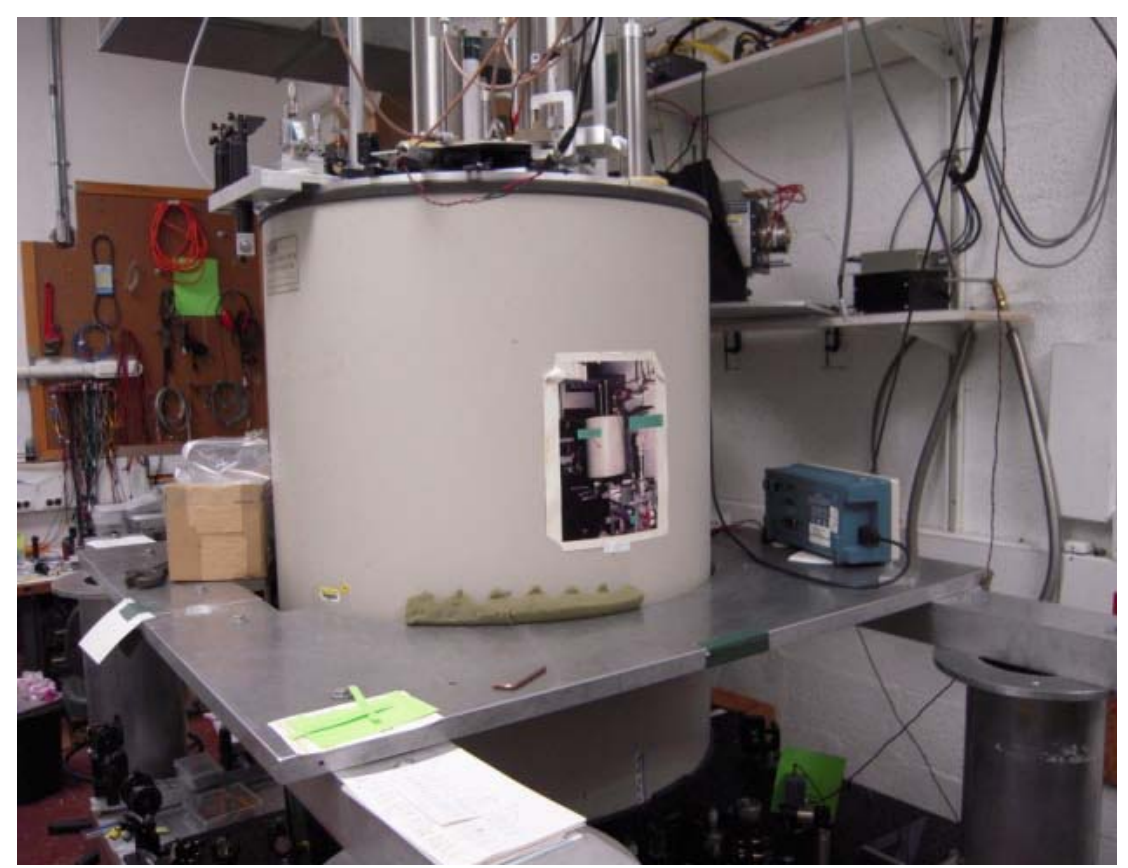

Figure 1. Superconducting magnet.

\section{Interoperability Communications Laboratory}

This laboratory conducted research on emergency response radio communications. VHF (160-170 MHz) and UHF (410-420 MHz) signals were transmitted by roof-mounted dipole antennas for this research. The VHF and UHF control channels transmitted continuously, while VHF and UHF traffic channels transmitted after they were automatically assigned to portable radio users.

Three employees worked at this laboratory during our evaluation. 


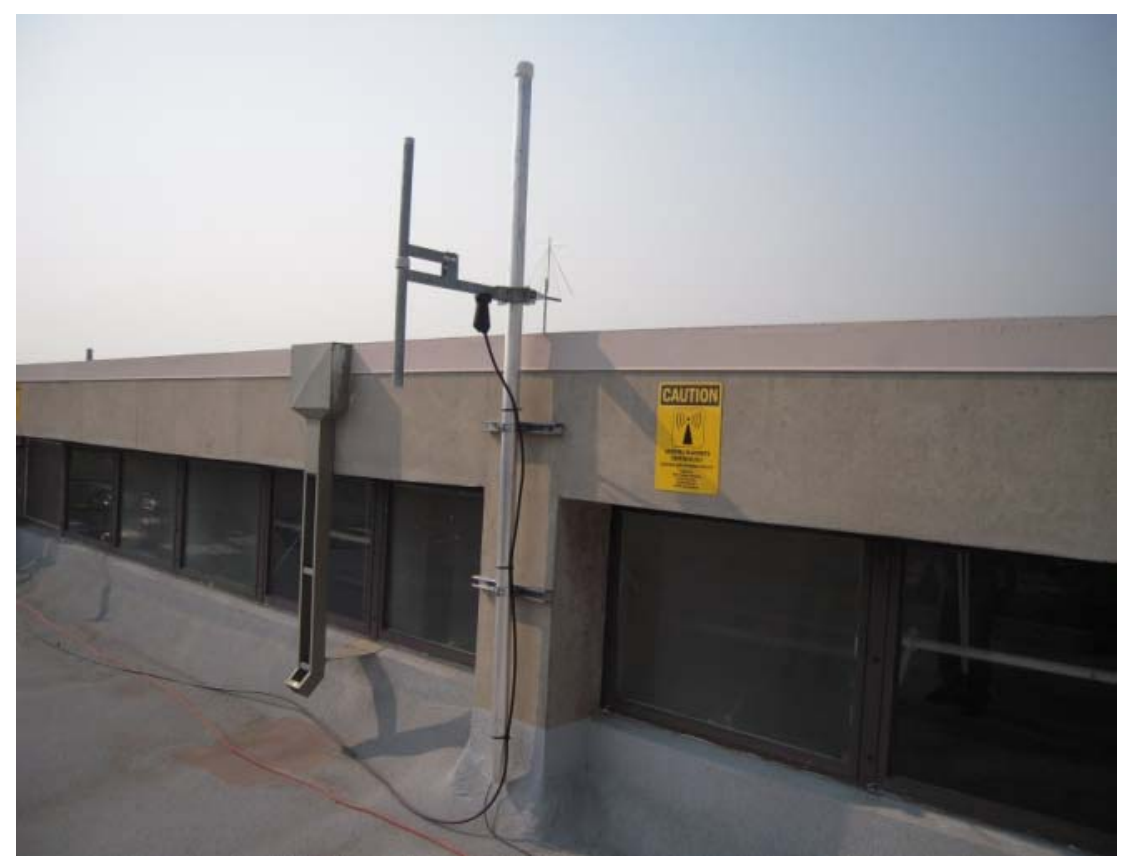

Figure 2. Interoperability communications laboratory roof-mounted antenna with caution sign located next to the antenna.

\section{Atomic Time Radio Stations}

The atomic time radio stations were located at a site in Colorado separate from the research institution's laboratories. Five employees worked at the radio stations during our evaluation. The LF radio station continuously broadcasted time and frequency signals at $60 \mathrm{kHz}$. The $\mathrm{LF}$ radio station used two identical antennas-a north antenna and a south antenna. Each antenna was a top loaded monopole consisting of four 400-foot towers arranged in a diamond shape. A system of cables (called a "top hat" by station employees) was suspended between the four towers. This top hat was electrically isolated from the towers and was electrically connected to a downlead suspended from the center of the top hat. The combination of the top hat and downlead served as the radiating element. The downlead of each antenna was terminated at its own helix house under the top hats. Each helix house contained a large helical inductor to cancel the capacitance of the short antenna and a variometer (variable inductor) to tune the antenna system. Each transmitter only had to produce a power of about $54 \mathrm{~kW}$ for LF to produce its effective radiated power of 70 kW [National Institute of Standards and Technology 2010a]. 
The HF radio station broadcasted time and frequency information including time announcements, standard time intervals, standard frequencies, geophysical alerts, marine storm warnings, and GPS status reports. The station radiated $10 \mathrm{~kW}$ on $5-, 10$-, and $15-\mathrm{MHz}$ dipole antennas; and $2.5 \mathrm{~kW}$ on 2.5 - and $20-\mathrm{MHz}$ dipole antennas. Each frequency was broadcast from a separate transmitter. Each antenna was mounted on a tower approximately one halfwavelength in height. The tallest tower $(2.5 \mathrm{MHz})$ was about 200 feet in height; the shortest tower $(20 \mathrm{MHz})$ was about 25 feet in height [National Institute of Standards and Technology 2010b].

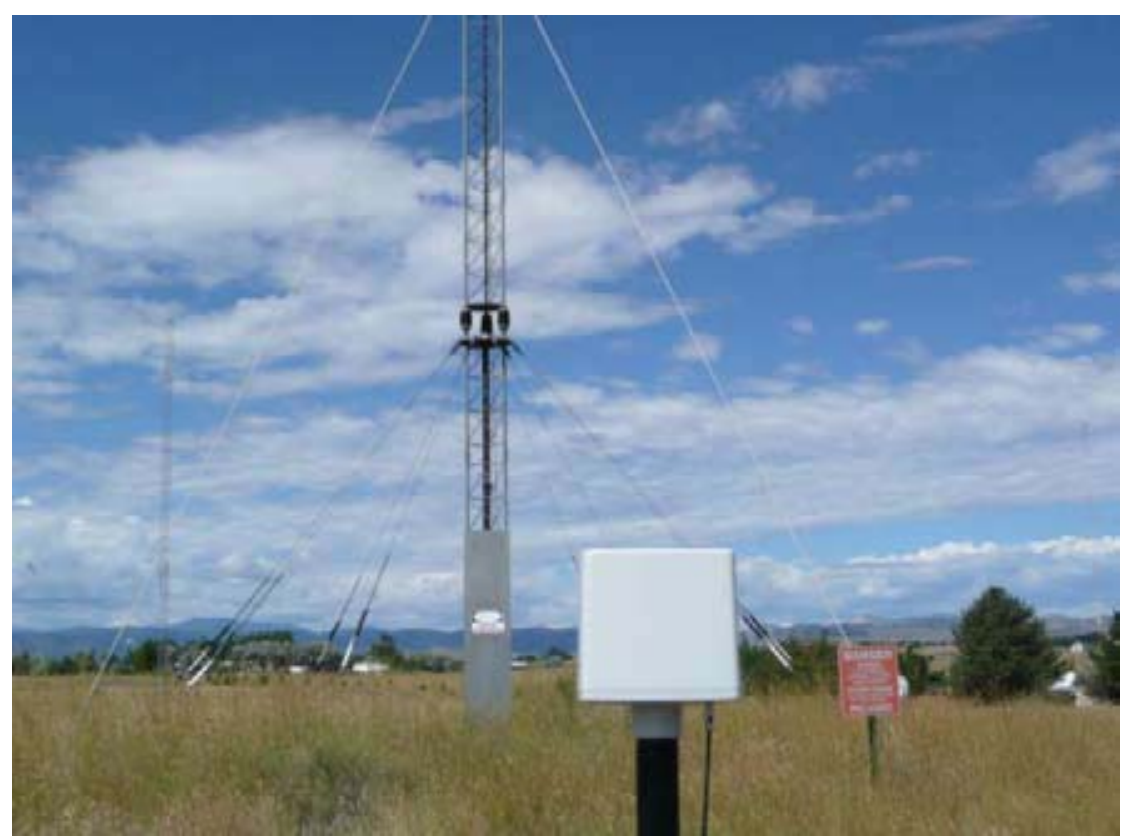

Figure 3. HF radio station antennas (background) with RF meter in the foreground. 


\section{Magnetic Annealer and Superconducting Magnet Laboratory}

We used an F.W. Bell® (Milwaukie, Oregon) Model 5170 meter with Model STH17-0404 transverse (DC-10 kHz) probe to measure RMS B-fields emanating from the annealer and superconducting magnet. This meter was calibrated within 1 year of the evaluation. Measurements were collected at various heights and distances from the annealer and superconducting magnet. The B-fields were compared to the following OELs (ceiling limits): ICNIRP occupational limits of exposure [ICNIRP 2009], IEEE MPE levels for the controlled environment [IEEE 2002], and ACGIH TLVs [ACGIH 2010]. Table 1 summarizes the OELs (ceiling limits). Appendix A provides a general discussion of OELs and the basis of the OELs and action levels referenced in this report.

Table 1. OELs (ceiling limits) for static B-fields (mT) with the most conservative OELs bolded

\begin{tabular}{|c|c|c|c|c|c|c|}
\hline \multicolumn{2}{|c|}{ ICNIRP } & \multicolumn{2}{|c|}{ IEEE } & \multicolumn{3}{|c|}{ ACGIH } \\
\hline $\begin{array}{l}\text { Head and } \\
\text { trunk }\end{array}$ & Limbs & $\begin{array}{l}\text { Head and } \\
\text { torso }\end{array}$ & $\begin{array}{c}\text { Arms or } \\
\text { legs }\end{array}$ & $\begin{array}{l}\text { Whole } \\
\text { body }\end{array}$ & Limbs & $\begin{array}{l}\text { Medical device } \\
\text { wearers }\end{array}$ \\
\hline 2000 & 8000 & 353 & 353 & 2000 & 20000 & 0.50 \\
\hline
\end{tabular}

\section{Interoperability Communications Laboratory}

We used a Holaday (ETS-Lindgren ${ }^{\mathrm{TM}}$, Cedar Park, Texas) HI4460 meter and HI-4433-STE isotropic E-field probe $(0.5 \mathrm{MHz}-5$ $\mathrm{GHz})$ to measure VHF (160-170 MHz) and UHF (410-420 MHz) E-fields. The meter and E-field probe were calibrated within 1 month of the evaluation. The E-field probe measured the field strength in each of three axes. The probe performed vector addition calculation on the readings from each axis and sent the RMS vector magnitude to the meter via a fiber optic cable to minimize field perturbation during measurements. Measurements were recorded near the roof-mounted antennas, near an employee when he was talking and holding transmitting radios, and in the offices inside the laboratory. To compare these measurements to the OELs with their 6-minute averaging time, the conservative assumption was made that employees could be exposed continuously for 6 minutes at the sampling locations. The E-field strengths were compared to the following OELs: ICNIRP reference 
levels for occupational exposures [ICNIRP 1998], IEEE MPEs for the upper tier (people in controlled environments) [IEEE 2005b], ACGIH TLVs [ACGIH 2010], and FCC limits for occupational/ controlled exposure [FCC 1999]. In addition, E-field strengths were compared to the following action levels as recommended by IEEE Standard C95.7-2005 [IEEE 2005a]: ICNIRP reference levels for general public exposure [ICNIRP 1998], IEEE action levels (general public) [IEEE 2005b], 1/5 the ACGIH TLVs [ACGIH 2010], and FCC limits for general population/uncontrolled exposure [FCC 1999]. Table 2 summarizes the OELs and action levels for E-field strengths at frequencies encountered in the interoperability communications laboratory.

Table 2. OELs and action levels (RMS values averaged over 6 minutes) for VHF and UHF E-field strengths $(\mathrm{V} / \mathrm{m})$ with the most conservative OELs bolded and action levels underlined

\begin{tabular}{|c|c|c|c|c|c|c|c|c|}
\hline \multirow{2}{*}{ Frequency (MHz) } & \multicolumn{2}{|c|}{ ICNIRP } & \multicolumn{2}{|c|}{ IEEE } & \multicolumn{2}{|c|}{ ACGIH } & \multicolumn{2}{|c|}{ FCC } \\
\hline & OEL & $\begin{array}{c}\text { Action } \\
\text { level }\end{array}$ & OEL & $\begin{array}{c}\text { Action } \\
\text { level }\end{array}$ & OEL & $\begin{array}{c}\text { Action } \\
\text { level }\end{array}$ & OEL & $\begin{array}{c}\text { Action } \\
\text { level }\end{array}$ \\
\hline VHF $160-170$ & 61 & 28 & 61 & 28 & 61 & $\underline{12}$ & 61 & 28 \\
\hline UHF $410-420$ & 61 & $\underline{28}$ & $72^{*}$ & $\underline{28^{*}}$ & $72^{*}$ & $\underline{28^{*}}$ & $72^{*}$ & $32^{*}$ \\
\hline
\end{tabular}

* IEEE, ACGIH, and FCC OELs and action levels for UHF $(410 \mathrm{MHz})$ were converted from power density $\left(\mathrm{W} / \mathrm{m}^{2}\right)$ to E-field strengths $(\mathrm{V} / \mathrm{m})$ using the following formula: $\mathrm{V} / \mathrm{m}=\sqrt{ }\left(377 \times \mathrm{W} / \mathrm{m}^{2}\right)$.

\section{Atomic Time Radio Stations}

We used a Narda (Hauppauge, New York) EHP-200 E- and H-field Analyzer $(9 \mathrm{kHz}-30 \mathrm{MHz})$ calibrated within 1 month of the survey to measure $\mathrm{E}$ - and $\mathrm{H}$-fields at various broadcasted frequencies. The analyzer was rented by management at the research institution for our use. The isotropic probe connected to a laptop computer (with NardaProbe software installed) via fiber optic cable to minimize field perturbation during measurements. Field strengths were measured on the three separate axes and recorded individually or combined as average RMS values over a 30-second sampling period. Thirty-second averaging times were used instead of 6-minute averaging times (required by most standards). A shorter averaging time was used because, according to our direct readings, the $\mathrm{E}$ - and $\mathrm{H}$-field strengths at a stationary position were generally constant. The conservative assumption was made that employees could be exposed continuously for 6 minutes at the sampling locations. 
The probe was positioned on a fiberglass tripod $\sim 2.5$ feet above the ground for most measurements. Measurements were collected around the $\mathrm{LF}$ antennas $(0.06 \mathrm{MHz})$ and $\mathrm{HF}$ antennas $(2.5-, 5-, 10$-, $15-$, and $20-\mathrm{MHz}$ ) as well as other areas around the radio stations. A few measurements were collected at head $(\sim 5.5$ feet $)$, chest $(\sim 4$ feet), and groin height $(\sim 2.5$ feet $)$ for relatively high E-fields to demonstrate variability over the human body and to provide data for spatial averaging (required by most standards). The E- and $\mathrm{H}$-field strengths were compared to the following OELs: ICNIRP reference levels for occupational exposures [ICNIRP 1998], IEEE MPEs for the upper tier (people in controlled environments) [IEEE 2005b], ACGIH TLVs [ACGIH 2010], and FCC limits for occupational/controlled exposure [FCC 1999]. In addition, E- and $\mathrm{H}$-field strengths were compared to the following action levels as recommended by IEEE Standard C95.7-2005 [IEEE 2005a]: ICNIRP reference levels for general public exposure [ICNIRP 1998], IEEE action levels (general public) [IEEE 2005b], 1/5 the ACGIH TLVs [ACGIH 2010], and FCC limits for general public/ uncontrolled exposure [FCC 1999]. Table 3 summarizes the OELs and action levels for the E-field strengths at the frequencies encountered at the radio stations. Table 4 summarizes the OELs and action levels for the H-field strengths at the frequencies encountered at the radio stations.

Because the HF radio station broadcasted multiple frequencies, mixture analysis was performed for $\mathrm{E}$ - and $\mathrm{H}$-field strengths by taking the sum of the ratios of the time-averaged squares of the measured field strengths to the corresponding squares of the OELs as described in Annex D.2 of IEEE Standard C95.1-2005 [IEEE 2005b]. To comply with OELs, the sum of the ratios should not exceed unity. This formula was also used after spatially averaging the squares of the E-field strengths (where measured at head, chest, and groin height) to strictly comply with both the mixture analysis and spatial averaging elements of the OELs. 
ASSESSMENT

(CONTINUED)

Table 3. OELs and action levels (RMS values averaged over 6 minutes) for LF and HF E-field strengths (V/m) with the most conservative OELs bolded and action levels underlined

\begin{tabular}{|c|c|c|c|c|c|c|c|c|}
\hline \multirow{2}{*}{ Frequency $(\mathrm{MHz})$} & \multicolumn{2}{|c|}{ ICNIRP } & \multicolumn{2}{|c|}{ IEEE } & \multicolumn{2}{|c|}{ ACGIH } & \multicolumn{2}{|c|}{ FCC } \\
\hline & OEL & $\begin{array}{c}\text { Action } \\
\text { level }\end{array}$ & OEL & $\begin{array}{c}\text { Action } \\
\text { level }\end{array}$ & OEL & $\begin{array}{c}\text { Action } \\
\text { level }\end{array}$ & OEL & $\begin{array}{c}\text { Action } \\
\text { level }\end{array}$ \\
\hline LF 0.06 & 610 & $\underline{87}$ & 1842 & 614 & 1842 & 368 & NA & NA \\
\hline HF 2.5 & 244 & $\underline{55}$ & 737 & 330 & 737 & 147 & 614 & 330 \\
\hline HF 5 & 122 & $\underline{40}$ & 368 & 165 & 368 & 74 & 368 & 165 \\
\hline HF 10 & 61 & $\underline{28}$ & 184 & 82 & 184 & 37 & 184 & 82 \\
\hline HF 15 & 61 & 28 & 123 & 55 & 123 & $\underline{25}$ & 123 & 55 \\
\hline HF 20 & 61 & 28 & 92 & 41 & 92 & 18 & 92 & 41 \\
\hline
\end{tabular}

Table 4. OELs and action levels (RMS values averaged over 6 minutes) for LF and HF H-field strengths (A/m) with the most conservative OELs bolded and action levels underlined

\begin{tabular}{|c|c|c|c|c|c|c|c|c|}
\hline \multirow{2}{*}{ Frequency (MHz) } & \multicolumn{2}{|c|}{ ICNIRP } & \multicolumn{2}{|c|}{ IEEE } & \multicolumn{2}{|c|}{ ACGIH } & \multicolumn{2}{|c|}{ FCC } \\
\hline & OEL & $\begin{array}{c}\text { Action } \\
\text { level }\end{array}$ & OEL & $\begin{array}{c}\text { Action } \\
\text { level }\end{array}$ & OEL & $\begin{array}{c}\text { Action } \\
\text { level }\end{array}$ & OEL & $\begin{array}{c}\text { Action } \\
\text { level }\end{array}$ \\
\hline LF 0.06 & 24.4 & $\underline{5}$ & $490^{*}$ & $163^{*}$ & 815 & 163 & NA & NA \\
\hline HF 2.5 & 0.64 & $\underline{0.3}$ & 6.5 & 6.5 & 6.5 & 1.30 & 1.63 & 0.88 \\
\hline HF 5 & 0.32 & $\underline{0.15}$ & 3.3 & 3.3 & 3.3 & 0.65 & 0.98 & 0.44 \\
\hline HF 10 & 0.16 & $\underline{0.073}$ & 1.6 & 1.6 & 1.7 & 0.33 & 0.49 & 0.22 \\
\hline HF 15 & 0.16 & $\underline{0.073}$ & 1.1 & 1.1 & 1.1 & 0.22 & 0.33 & 0.15 \\
\hline HF 20 & 0.16 & $\underline{0.073}$ & 0.82 & 0.82 & 0.8 & 0.16 & 0.24 & 0.11 \\
\hline
\end{tabular}

${ }^{*}$ IEEE OEL and action level for $0.06 \mathrm{MHz}$ are for head and torso (OEL and action level for limbs are $900 \mathrm{~A} / \mathrm{m}$ ). 


\section{Magnetic Annealer Laboratory}

One measurement was collected within 1 inch of the annealing chamber. The B-field at this location was $0.4 \mathrm{mT}$, below the ACGIH TLV ceiling limit of $0.5 \mathrm{mT}$ for medical device wearers. The B-fields dropped rapidly with increasing distance from the annealer.

\section{Superconducting Magnet Laboratory}

Table 5 summarizes the B-field measurements collected in the superconducting magnet laboratory. B-fields exceeding the ACGIH TLV ceiling limit for medical device wearers $(0.5 \mathrm{mT})$ are bolded. No B-fields exceeded any of the other OELs. A sign warning of possible interference with pacemakers was posted on the door of the laboratory, and the $0.5 \mathrm{mT}$ field was delineated with tape on the floor ( $\sim 6$ feet from the magnet). 
RESULTS

\section{(CONTINUED)}

Table 5. Static EMF B-fields measured in the superconducting magnet laboratory with field strengths above the ACGIH TLV ceiling limit for medical device wearers bolded

\begin{tabular}{llll}
\hline Location of measurement & $\begin{array}{l}\text { Height of measurement } \\
\text { (relative to employee } \\
\text { position) }\end{array}$ & $\begin{array}{c}\text { Distance from } \\
\text { magnet (inches) }\end{array}$ & $\begin{array}{c}\text { B-field } \\
(\mathrm{mT})\end{array}$ \\
\hline Mirror under the magnet & Hands (while cleaning mirror) & 0 & $\mathbf{1 7 4}$ \\
To the right of the magnet & Chest (while standing) & 1 & $\mathbf{6 5}$ \\
To the left of the magnet & Stomach (while standing) & 1 & $\mathbf{4 0}$ \\
To the right of the magnet & Head (while standing) & 1 & $\mathbf{4 0}$ \\
To the right of the magnet & Waist (while standing) & 1 & $\mathbf{3 3}$ \\
To the left of the magnet & Head (while standing) & 18 & $\mathbf{9 . 7}$ \\
To the right of the magnet & Chest (while standing) & 24 & $\mathbf{6 . 5}$ \\
Optics workstation in front of the magnet & Head (while sitting) & 24 & $\mathbf{1 . 3}$ \\
Optics workstation in front of the magnet & Stomach (while standing) & 36 & 0.12 \\
To the right of the magnet & Chest (while standing) & 72 & 0.080 \\
To the right of the magnet & Chest (while standing) & 90 & 0.080 \\
\hline
\end{tabular}

\section{Interoperability Communications Laboratory}

E-field strengths at the VHF and UHF frequencies measured in the interoperability communications laboratory and near the roofmounted antennas are summarized in Table 6. E-field strengths above the most conservative OELs $(61 \mathrm{~V} / \mathrm{m})$ are bolded and action levels $(12 \mathrm{~V} / \mathrm{m}$ for $160-170 \mathrm{MHz}$ and $28 \mathrm{~V} / \mathrm{m}$ for $410-420 \mathrm{MHz}$ ) underlined. We did not measure E-field strengths in the office while the traffic channel was transmitting. However, we would not expect the traffic channel to add substantially to the field strengths in the office because the field strengths in the office were so low. During our evaluation, no portable radios were affiliated onto the VHF antenna facing the mountains. Thus, only a control channel transmitted on this antenna. If a traffic channel also transmitted, 
then we would expect similar field strengths to those measured at the VHF antenna facing the road. On the roof, signs posted next to the antennas cautioned people to stay 8 feet away because of continuous transmission. Measurements were taken at 7.5 feet away from the antennas to ensure safety and compliance with applicable standards. E-field strengths at these locations were well below OELs and action levels.

Table 6. VHF and UHF E-field strengths measured in the interoperability communications laboratory with field strengths above OELs bolded and action levels underlined

\begin{tabular}{|c|c|c|c|c|c|}
\hline \multirow[b]{2}{*}{ General area } & \multirow[b]{2}{*}{ Description } & \multirow{2}{*}{$\begin{array}{l}\text { Height of } \\
\text { measurement } \\
\text { (relative to } \\
\text { employee } \\
\text { position) }\end{array}$} & \multirow[b]{2}{*}{$\begin{array}{l}\text { Frequency } \\
\quad(\mathrm{MHz})\end{array}$} & \multicolumn{2}{|c|}{ E-field (V/m) } \\
\hline & & & & $\begin{array}{l}\text { Control } \\
\text { channel } \\
\text { only }\end{array}$ & $\begin{array}{l}\text { Control and } \\
\text { traffic channel }\end{array}$ \\
\hline Inside the laboratory & Office & Stomach & 160 & 0 & DNR \\
\hline Inside the laboratory & Office & Stomach & 410 & 0 & DNR \\
\hline Inside the laboratory & $\begin{array}{l}\text { Holding VHF portable } \\
\text { adio out to the side }\end{array}$ & Hand & 160 & NA & 80 \\
\hline Inside the laboratory & $\begin{array}{l}\text { Talking on the VHF } \\
\text { portable radio (close to } \\
\text { mouth) }\end{array}$ & Mouth & 160 & NA & 134 \\
\hline Inside the laboratory & $\begin{array}{l}\text { Talking on the VHF } \\
\text { portable radio ( } 1 \text { foot from } \\
\text { mouth) }\end{array}$ & Mouth & 160 & NA & 0 \\
\hline Inside the laboratory & $\begin{array}{l}\text { Talking on UHF portable } \\
\text { radio (close to mouth) }\end{array}$ & Mouth & 160 & NA & 78 \\
\hline Inside the laboratory & $\begin{array}{l}\text { Talking on UHF portable } \\
\text { radio (close to mouth) }\end{array}$ & Forehead & 160 & NA & $\underline{22}$ \\
\hline On roof facing the road & 1 foot from VHF antenna & Stomach & 160 & $\underline{47}$ & 76 \\
\hline On roof facing the road & 4.5 feet from VHF antenna & Stomach & 160 & 12 & $\underline{29}$ \\
\hline On roof facing the road & 7.5 feet from VHF antenna & Stomach & 160 & 0 & $\underline{14}$ \\
\hline $\begin{array}{l}\text { On roof facing the } \\
\text { mountains }\end{array}$ & 1 foot from VHF antenna & Stomach & 160 & $\underline{48}$ & NA \\
\hline $\begin{array}{l}\text { On roof facing the } \\
\text { mountains }\end{array}$ & 4.5 feet from VHF antenna & Stomach & 160 & 5 & NA \\
\hline $\begin{array}{l}\text { On roof facing the } \\
\text { mountains }\end{array}$ & 7.5 feet from VHF antenna & Stomach & 160 & 0 & NA \\
\hline On roof facing the road & 1 foot from UHF antenna & Stomach & 410 & $\underline{57}$ & 101 \\
\hline On roof facing the road & 4.5 feet from UHF antenna & Stomach & 410 & 5 & $\underline{36}$ \\
\hline On roof facing the road & 7.5 feet from UHF antenna & Stomach & 410 & 8.3 & 0 \\
\hline
\end{tabular}




\section{Atomic Time Radio Stations}

Figure 4 is a map of the grounds surrounding the atomic time radio stations. $\mathrm{E}$ - and $\mathrm{H}$-field measurements were collected in six distinct areas, which are highlighted by red or blue ovals. All measurements at the atomic time radio stations and sampling information (including mixture analyses and recorded GPS coordinates) are provided in Appendix B for E-fields and Appendix $\mathrm{C}$ for $\mathrm{H}$-fields. E- and $\mathrm{H}$-field strengths measured in the HF building, LF building, and at the main gate were all well below action levels.

The following four tables present $\mathrm{E}$ - and $\mathrm{H}$-field strengths around the LF and HF antennas that are representative of all the measurements collected in these areas. Sample numbers are provided to allow readers to cross reference the measurements in the body of the report with the measurements in Appendix B and $\mathrm{C}$. Table 7 presents the $\mathrm{E}$ - and $\mathrm{H}$-field strengths for the RF measured near the HF antennas. Field strengths above the most conservative OELs are bolded and action levels underlined (Tables 3 and 4). E- and $\mathrm{H}$-field strengths exceeded the most conservative OELs near the 10- and 15-MHz antennas. E- and H-field strengths above the most conservative action levels were measured along the access road circling the HF antennas. More than one frequency contributed $>10 \%$ of the OEL to the overall E-field strengths at a number of locations. Thus, the sums of ratios (squared field strengths/squared OELs or action levels) are provided for each sampling location. Ratios above unity represent areas where the total field strengths exceeded OELs or action levels. It is important to note that the LF E- and $\mathrm{H}$-field strengths measured at the HF antennas were insignificant $(<1 \%$ of the OEL).

Tables 8 and 9 present the E- and H-field strengths for the LF north and south antennas. No field strengths exceeded the OELs for $0.06 \mathrm{MHz}$ (Tables 3 and 4). However, E-field strengths did exceed the most conservative action level for $0.06 \mathrm{MHz}$ along the access roads leading to the helix houses. It is important to note that the HF E- and H-field strengths measured at the LF antennas were insignificant $(<1 \%$ of the OEL).

The results presented thus far were collected at groin height. To strictly comply with OELs, E- and $\mathrm{H}$-fields should be spatially averaged over an area equivalent to the vertical cross section of the human body. Table 10 presents spatially averaged E- and H-fields 
measured at locations where field strengths were among the highest. According to this table, the highest E-fields were at groin height. Although some individual measurements at groin height did exceed OELs, the spatial averages were below OELs, and the ratios to OELs were below unity for all locations. We found that the polarization of the E-fields was predominately along the z-axis (vertical direction) near the LF and HF antennas.

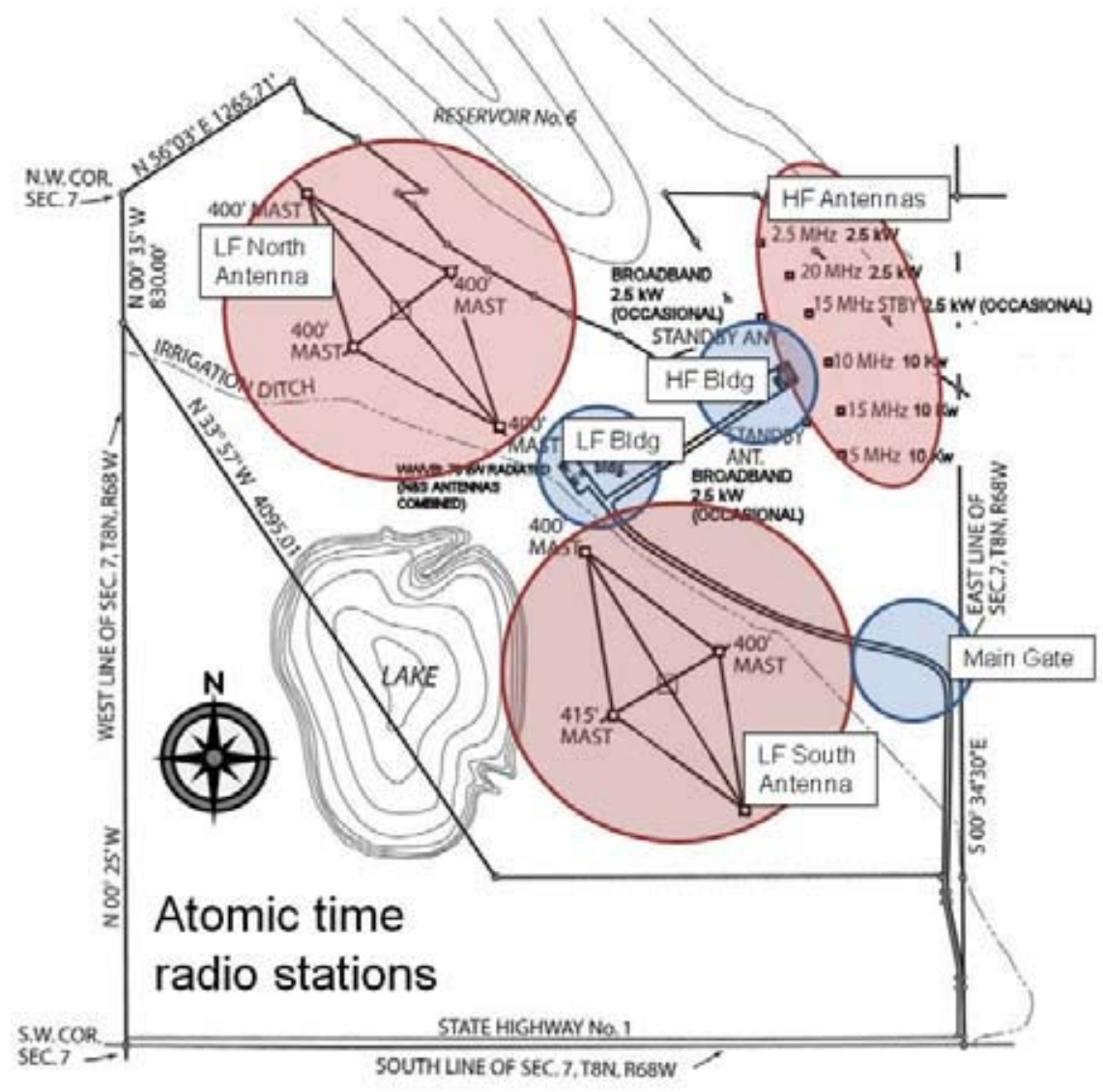

Figure 4. Map of the grounds of the atomic time radio stations with red and blue ovals identifying areas where measurements were collected. 
RESULTS

\section{(CONTINUED)}

Table 7. RF E- and H-field strengths measured at the HF antennas with the field strengths above OELs bolded and action levels underlined

\begin{tabular}{|c|c|c|c|c|c|c|c|c|}
\hline \multirow[b]{2}{*}{$\begin{array}{l}\text { Sample } \\
\text { No. }\end{array}$} & \multirow[b]{2}{*}{ Sample location } & \multirow[b]{2}{*}{$\begin{array}{l}\text { Freq. } \\
(\mathrm{MHz})\end{array}$} & \multicolumn{3}{|c|}{ E-field } & \multicolumn{3}{|c|}{ H-field } \\
\hline & & & $\begin{array}{l}\text { Strength } \\
(\mathrm{V} / \mathrm{m})\end{array}$ & $\begin{array}{l}\text { Ratio } \\
\text { to } \\
\text { OELs }\end{array}$ & $\begin{array}{l}\text { Ratio } \\
\text { to } \\
\text { action } \\
\text { levels }\end{array}$ & $\begin{array}{l}\text { Strength } \\
(\mathrm{A} / \mathrm{m})\end{array}$ & $\begin{array}{l}\text { Ratio } \\
\text { to } \\
\text { OELs }\end{array}$ & $\begin{array}{l}\text { Ratio } \\
\text { to } \\
\text { action } \\
\text { levels }\end{array}$ \\
\hline \multirow{2}{*}{3,4} & \multirow{2}{*}{$\begin{array}{l}\text { On access road, near } 5-\mathrm{MHz} \\
\text { antenna }\end{array}$} & & 29 & \multirow{2}{*}{0.1} & \multirow{2}{*}{0.9} & & \multirow{2}{*}{0.1} & \multirow{2}{*}{0.5} \\
\hline & & 15 & 14 & & & 0.027 & & \\
\hline \multirow{2}{*}{$120 \mathrm{E}, \mathrm{H}$} & \multirow{2}{*}{$\begin{array}{l}\text { On access road, } 30 \text { feet from } \\
\text { south } 15-\mathrm{MHz} \text { antenna }\end{array}$} & 10 & 13 & \multirow{2}{*}{3.0} & \multirow{2}{*}{18} & 0.024 & \multirow{2}{*}{2.7} & \multirow{2}{*}{13} \\
\hline & & 15 & 105 & & & 0.26 & & \\
\hline \multirow{2}{*}{$121 \mathrm{E}, \mathrm{H}$} & \multirow{2}{*}{$\begin{array}{l}\text { On access road, } 60 \text { feet from } \\
\text { south } 15-\mathrm{MHz} \text { antenna }\end{array}$} & 5 & 15 & \multirow{2}{*}{1.0} & \multirow{2}{*}{5.8} & 0.033 & \multirow{2}{*}{0.5} & \multirow{2}{*}{2.4} \\
\hline & & 15 & $\underline{59}$ & & & $\underline{0.11}$ & & \\
\hline \multirow{2}{*}{7,8} & \multirow{2}{*}{$\begin{array}{l}\text { On access road, between south } \\
15-\text { and } 10-\mathrm{MHz} \text { antennas }\end{array}$} & 10 & 19 & \multirow{2}{*}{0.3} & \multirow{2}{*}{1.8} & 0.031 & \multirow{2}{*}{0.2} & \multirow{2}{*}{1.0} \\
\hline & & 15 & $\underline{28}$ & & & 0.067 & & \\
\hline \multirow{2}{*}{$116 \mathrm{E}, \mathrm{H}$} & \multirow{2}{*}{$\begin{array}{l}\text { In the field, } 30 \text { feet from } 10-\mathrm{MHz} \\
\text { antenna }\end{array}$} & 10 & 80 & \multirow{2}{*}{1.8} & \multirow{2}{*}{8.6} & 0.19 & \multirow{2}{*}{1.4} & 70 \\
\hline & & 15 & 15 & & & 0.030 & & 1.0 \\
\hline & On access road, 50 feet from & 10 & $\underline{54}$ & & & $\underline{0.14}$ & & \\
\hline $115 \mathrm{E}, \mathrm{H}$ & $10-\mathrm{MHz}$ antenna & 15 & $\underline{11}$ & 0.8 & 3.9 & $\underline{0}$ & 0.8 & 3.7 \\
\hline 11,12 & $\begin{array}{l}\text { On access road, between north } \\
10-\text { and } 15-\mathrm{MHz} \text { antennas }\end{array}$ & 10 & 22 & 0.1 & 0.7 & 0.055 & 0.1 & 0.6 \\
\hline 13,14 & $\begin{array}{l}\text { On access road, near north } \\
15-\mathrm{MHz} \text { antenna (antenna off) }\end{array}$ & 10 & 10 & 0 & 0.2 & 0.028 & 0 & 0.2 \\
\hline 15,16 & $\begin{array}{l}\text { On access road, between } \\
15-\text { and } 20-\mathrm{MHz} \text { antennas }\end{array}$ & 20 & 11 & 0 & 0.5 & 0.021 & 0 & 0.1 \\
\hline $110 \mathrm{E}, \mathrm{H}$ & $\begin{array}{l}\text { On access road, } 30 \text { feet from } \\
20-\mathrm{MHz} \text { antenna }\end{array}$ & 20 & $\underline{50}$ & 0.7 & 7.6 & $\underline{0.1}$ & 0.4 & 1.7 \\
\hline 19,20 & $\begin{array}{l}\text { On access road, between } \\
20-\text { and } 2.5-\mathrm{MHz} \text { antennas }\end{array}$ & 20 & 11 & 0 & 0.4 & 0.023 & 0 & 0.1 \\
\hline 21,22 & $\begin{array}{l}\text { On access road, near } \\
2.5-\mathrm{MHz} \text { antenna }\end{array}$ & 2.5 & 20 & 0 & 0.2 & 0.035 & 0 & 0.1 \\
\hline 23,24 & $\begin{array}{l}\text { On access road, near north } \\
\text { broadband antenna (antenna off) }\end{array}$ & 2.5 & 9.4 & 0 & 0.1 & 0.015 & 0 & 0.1 \\
\hline $117 \mathrm{E}, \mathrm{H}$ & $\begin{array}{l}\text { Fence line east of the } \\
10-\mathrm{MHz} \text { antenna }\end{array}$ & 10 & 3.6 & 0 & 0 & 0.022 & 0 & 0.1 \\
\hline
\end{tabular}


RESULTS

\section{(CONTINUED)}

Table 8. E- and $\mathrm{H}$-field strengths measured at the LF north antenna with E-field strengths above the action level underlined

\begin{tabular}{|c|c|c|c|c|}
\hline Sample No. & Sample location & $\begin{array}{l}\text { Freq. } \\
(\mathrm{MHz})\end{array}$ & $\begin{array}{l}\text { E-field strength } \\
\qquad(\mathrm{V} / \mathrm{m})\end{array}$ & $\begin{array}{l}\mathrm{H} \text {-field strength } \\
(\mathrm{A} / \mathrm{m})\end{array}$ \\
\hline $90 \mathrm{E}$ & $\begin{array}{l}\text { Concrete slab outside the helix house } \\
\text { entrance }\end{array}$ & 0.06 & 44 & 2.1 \\
\hline $91 \mathrm{E}$ & $\begin{array}{l}\text { Just inside the entrance of the helix } \\
\text { house }\end{array}$ & 0.06 & 12 & 0.27 \\
\hline $92 \mathrm{E}$ & $\begin{array}{l}\text { Next to the aluminum gate inside the } \\
\text { helix house }\end{array}$ & 0.06 & 68 & 2.4 \\
\hline $93 \mathrm{E}$ & 70 feet north of the helix house & 0.06 & $\underline{444}$ & 1.8 \\
\hline $95 \mathrm{E}$ & $\begin{array}{l}\text { Near anchor for the radio tower north of } \\
\text { the helix house }\end{array}$ & 0.06 & $\underline{113}$ & 0.70 \\
\hline $94 \mathrm{E}$ & $\begin{array}{l}\text { On access road, } 250 \text { feet north of the } \\
\text { helix house }\end{array}$ & 0.06 & $\underline{210}$ & 0.46 \\
\hline $89 \mathrm{E}$ & $\begin{array}{l}\text { On access road, } 15 \text { feet south of the } \\
\text { helix house }\end{array}$ & 0.06 & $\underline{230}$ & 1.5 \\
\hline $96 \mathrm{E}$ & $\begin{array}{l}\text { On access road, } 330 \text { feet south of the } \\
\text { helix house }\end{array}$ & 0.06 & $\underline{216}$ & 1.7 \\
\hline $97 \mathrm{E}$ & $\begin{array}{l}\text { On access road, } 550 \text { feet south of the } \\
\text { helix house }\end{array}$ & 0.06 & $\underline{203}$ & DNR \\
\hline $101 \mathrm{E}$ & $\begin{array}{l}\text { On access road, } 717 \text { feet south of the } \\
\text { helix house }\end{array}$ & 0.06 & $\underline{82}$ & DNR \\
\hline $99 \mathrm{E}$ & $\begin{array}{l}\text { On access road, } 785 \text { feet south of the } \\
\text { helix house }\end{array}$ & 0.06 & 67 & DNR \\
\hline $98 \mathrm{E}$ & $\begin{array}{l}\text { On access road, } 825 \text { feet south of the } \\
\text { helix house }\end{array}$ & 0.06 & 41 & DNR \\
\hline
\end{tabular}


RESULTS

(CONTINUED)

Table 9. E- and H-field strengths measured at the LF south antenna with E-field strengths above the action level underlined

\begin{tabular}{|c|c|c|c|c|}
\hline Sample No. & Sample location & $\begin{array}{l}\text { Freq. } \\
(\mathrm{MHz})\end{array}$ & $\begin{array}{l}\text { E-field strength } \\
(\mathrm{V} / \mathrm{m})\end{array}$ & $\begin{array}{l}\mathrm{H} \text {-field strength } \\
(\mathrm{A} / \mathrm{m})\end{array}$ \\
\hline $61 \mathrm{E}, 63 \mathrm{H}$ & Just outside the helix house & 0.06 & $\underline{255}$ & 1.8 \\
\hline $65 \mathrm{E}, 64 \mathrm{H}$ & $\begin{array}{l}\text { Straddling the doorway to the helix } \\
\text { house }\end{array}$ & 0.06 & 13 & 1.0 \\
\hline $67 \mathrm{E}, 66 \mathrm{H}$ & Just inside the helix house & 0.06 & $\underline{91}$ & 2.2 \\
\hline $77 \mathrm{E}, \mathrm{H}$ & $\begin{array}{l}\text { Next to aluminum gate in the helix } \\
\text { house }\end{array}$ & 0.06 & 58 & 2.9 \\
\hline $75 \mathrm{E}, \mathrm{H}$ & $\begin{array}{l}\text { Near anchor for radio tower south of } \\
\text { the helix house }\end{array}$ & 0.06 & $\underline{272}$ & 1.3 \\
\hline $74 \mathrm{E}$ & $\begin{array}{l}\text { On access road, } 20 \text { feet north of the } \\
\text { helix house }\end{array}$ & 0.06 & $\underline{152}$ & DNR \\
\hline $78 \mathrm{E}, \mathrm{H}$ & $\begin{array}{l}\text { On access road, } 35 \text { feet north of the } \\
\text { helix house }\end{array}$ & 0.06 & $\underline{250}$ & 0.88 \\
\hline $80 \mathrm{E}$ & $\begin{array}{l}\text { On access road, } 150 \text { feet north of the } \\
\text { helix house }\end{array}$ & 0.06 & $\underline{271}$ & DNR \\
\hline $82 \mathrm{E}$ & $\begin{array}{l}\text { On access road, } 700 \text { feet north of the } \\
\text { helix house }\end{array}$ & 0.06 & $\underline{91}$ & DNR \\
\hline $83 \mathrm{E}$ & $\begin{array}{l}\text { Entrance to access road leading to the } \\
\text { helix house }\end{array}$ & 0.06 & 38 & DNR \\
\hline
\end{tabular}


RESULTS

(CONTINUED)

Table 10. Spatially averaged $\mathrm{E}$ - and $\mathrm{H}$-field strengths for three locations with field strengths above OELs bolded and action levels underlined

\begin{tabular}{|c|c|c|c|c|c|c|c|c|c|c|c|}
\hline \multirow[b]{2}{*}{$\begin{array}{l}\text { Sample } \\
\text { location }\end{array}$} & \multirow[b]{2}{*}{$\begin{array}{l}\text { Sample } \\
\text { No. }\end{array}$} & \multirow[b]{2}{*}{$\begin{array}{l}\text { Freq. } \\
(\mathrm{MHz})\end{array}$} & \multirow[b]{2}{*}{ Height } & \multicolumn{4}{|c|}{ E-field } & \multicolumn{4}{|c|}{$\mathrm{H}$-field } \\
\hline & & & & $\begin{array}{c}\text { Strength } \\
(\mathrm{V} / \mathrm{m})\end{array}$ & $\begin{array}{c}\text { Spatial } \\
\text { average } \\
(\mathrm{V} / \mathrm{m})\end{array}$ & $\begin{array}{l}\text { Ratio } \\
\text { to } \\
\text { OELs }\end{array}$ & $\begin{array}{l}\text { Ratio } \\
\text { to } \\
\text { action } \\
\text { levels }\end{array}$ & $\begin{array}{c}\text { Strength } \\
(\mathrm{A} / \mathrm{m})\end{array}$ & $\begin{array}{c}\text { Spatial } \\
\text { average } \\
(\mathrm{A} / \mathrm{m})\end{array}$ & $\begin{array}{l}\text { Ratio } \\
\text { to } \\
\text { OELs }\end{array}$ & $\begin{array}{l}\text { Ratio } \\
\text { to } \\
\text { action } \\
\text { levels }\end{array}$ \\
\hline \multirow{3}{*}{$\begin{array}{l}\text { On access } \\
\text { road, } 30 \\
\text { feet from } \\
20-\mathrm{MHz} \\
\text { antenna }\end{array}$} & $122 \mathrm{E}$ & 20 & Head & $\underline{38}$ & & \multirow{3}{*}{ NA } & \multirow{3}{*}{ NA } & $\underline{0.077}$ & & \multirow{3}{*}{ NA } & \multirow{3}{*}{ NA } \\
\hline & $123 \mathrm{E}$ & 20 & Chest & $\underline{36}$ & $\underline{42}$ & & & $\underline{0.087}$ & $\underline{0.088}$ & & \\
\hline & $124 \mathrm{E}$ & 20 & Groin & $\underline{51}$ & & & & $\underline{0.098}$ & & & \\
\hline \multirow{6}{*}{$\begin{array}{l}\text { On access } \\
\text { road, } 50 \\
\text { feet from } \\
10-\mathrm{MHz} \\
\text { antenna }\end{array}$} & $127 \mathrm{E}$ & 10 & Head & $\underline{40.9}$ & & \multirow{6}{*}{0.55} & \multirow{6}{*}{2.7} & $\underline{0.15}$ & & \multirow{6}{*}{0.85} & \multirow{6}{*}{4.1} \\
\hline & $126 \mathrm{E}$ & 10 & Chest & $\underline{39}$ & $\underline{44}$ & & & $\underline{0.14}$ & $\underline{0.15}$ & & \\
\hline & $125 \mathrm{E}$ & 10 & Groin & 52 & & & & $\underline{0.15}$ & & & \\
\hline & $127 \mathrm{E}$ & 15 & Head & 8.4 & & & & 0.017 & & & \\
\hline & $126 \mathrm{E}$ & 15 & Chest & 8.1 & 10 & & & 0.017 & 0.018 & & \\
\hline & $125 \mathrm{E}$ & 15 & Groin & 12 & & & & 0.019 & & & \\
\hline \multirow{6}{*}{$\begin{array}{l}\text { On access } \\
\text { road, } 50 \\
\text { feet from } \\
15-\mathrm{MHz} \\
\text { antenna }\end{array}$} & $128 \mathrm{E}$ & 10 & Head & 7.9 & & \multirow{6}{*}{0.95} & \multirow{6}{*}{5.6} & 0.025 & & \multirow{6}{*}{0.90} & \multirow{6}{*}{4.3} \\
\hline & $129 \mathrm{E}$ & 10 & Chest & 8.5 & 10 & & & 0.026 & 0.024 & & \\
\hline & $130 \mathrm{E}$ & 10 & Groin & 12 & & & & 0.022 & & & \\
\hline & $128 \mathrm{E}$ & 15 & Head & $\underline{48.6}$ & & & & 0.16 & & & \\
\hline & $129 \mathrm{E}$ & 15 & Chest & $\underline{54}$ & $\underline{59}$ & & & $\underline{0.15}$ & $\underline{0.15}$ & & \\
\hline & $130 \mathrm{E}$ & 15 & Groin & 71 & & & & $\underline{0.14}$ & & & \\
\hline
\end{tabular}




\section{Static Magnetic Fields}

An important element of an EMF safety program is maintaining an inventory of relevant EMF sources. An EMF source should be considered relevant if it can produce field strengths (or other exposure metrics) near or above OELs or action levels. In this evaluation, the four relevant EMF sources we identified included (1) the magnetic annealer, (2) the superconducting magnet, (3) the interoperability communications radio antennas, and (4) the atomic time radio antennas. All these sources produced $\mathrm{E}-, \mathrm{H}-$, or B-fields that exceeded OELs or action levels except for the magnetic annealer. The B-field within 1 inch of the annealer $(0.4 \mathrm{mT})$ was just below the ACGIH TLV ceiling limit of $0.5 \mathrm{mT}$ for medical device wearers and consequently should be considered a relevant EMF source. The other sources we evaluated, (building 24 antenna laboratory and time domain laboratory) were low power and did not produce field strengths near OELs or action levels.

A sign warning of possible interference with pacemakers was posted on the door of the superconducting magnet laboratory. This sign was necessary because B-fields exceeded the ACGIH TLV ceiling limit of $0.5 \mathrm{mT}$ inside the laboratory (ranging up to $174 \mathrm{mT})$. The $0.5 \mathrm{mT}$ field inside the laboratory was delineated with tape on the floor ( 6 feet from the magnet). The B-field at this location was $0.12 \mathrm{mT}$, which is $<25 \%$ of the ACGIH TLV ceiling value for medical device wearers. Thus, if employees with pacemakers remain behind the $0.5 \mathrm{mT}$ line, they should be protected from EMF interference with the function of their pacemakers.

\section{Radio Frequencies}

To strictly comply with OELs for E- and $\mathrm{H}$-field strengths at RF $(100 \mathrm{kHz}-10 \mathrm{GHz})$ frequencies, RMS values should be averaged over 6 minutes, and spatial averaging should be conducted across the vertical cross section of the human body. However, we recorded average RMS values for 30 seconds instead of 6 minutes at the atomic time radio stations because our direct readings demonstrated that the field strengths were relatively constant. The E-field strengths we measured at the interoperability communications laboratory were instantaneous values. Spatial averaging was only conducted for relatively high E-fields at the atomic time radio stations. To interpret the results we assumed that (1) the RF sources are active throughout the day, (2) the 
employees could be exposed at the sample location continuously for 6 minutes, and (3) the field strengths that were not spatially averaged represented conservative estimates of exposure (i.e., do not underestimate potential exposures).

According to our measurements, employees could be exposed to E-field strengths exceeding the most conservative OELs at the interoperability communications laboratory. The greatest potential for exposure would occur if employees worked within 1 foot of the roof-mounted antennas while they were transmitting. Signs were posted next to these antennas cautioning employees to stay 8 feet away because of continuous transmission (control channel). E-field strengths at 7.5 feet from the antennas were well below the OELs. Thus, if employees remained 8 feet away from the antennas, their exposures would be well below OELs. However, for the $160-\mathrm{MHz}$ antenna on the roof facing the road, the E-field strength at 7.5 feet was just above the action level.

We measured E-field strengths above OELs when employees were operating portable radios inside the interoperability communications laboratory. These field strengths were highly localized and dropped rapidly with increasing distance from the radios. Therefore, spatial averaging across the human body would result in lower E-field strengths. Moreover, it is unlikely that employees would communicate continuously over the radios for 6 minutes. Nevertheless, RF exposures to the face are biologically relevant because the eyes are vulnerable to the thermal effects of RF [FCC 1999].

$\mathrm{E}$ - and $\mathrm{H}$-field strengths were measured at the atomic time radio stations to determine compliance with OELs. In general, E-field strengths were greater than $\mathrm{H}$-field strengths (relative to OELs). Our measurements at the atomic time radio stations indicate that employees could be exposed to $\mathrm{E}$ - and $\mathrm{H}$-field strengths above the most conservative OELs. The greatest potential for overexposure would occur if employees were to work near (within 30 feet) the $10-$ or $15-\mathrm{MHz}$ antennas while the antennas were broadcasting. However, according to radio station employees, these antennas would be deactivated and detuned if they were to be repaired. In these situations, E-field strengths from adjacent antennas would be the primary sources of exposure. E-field strengths from other antennas did contribute to the overall exposures. For example, 15-MHz E-field strengths above action levels were measured near the $10-\mathrm{MHz}$ antenna. However, none of the E-field strengths from adjacent antennas were above OELs. 
We know from the spatial averaging measurements that the E-field strengths at groin height were greater than those at chest and head height. Although OELs require spatial averaging, the most conservative approach is to collect measurements at a height where the field strengths are the highest. Most of the measurements we collected were at groin height. Thus, the majority of our measurements are conservative estimates of exposure. Additionally, the groin height measurements are biologically relevant because all the radio station employees were male, and the testes are particularly vulnerable to the thermal effects of radio frequencies [FCC 1999].

Compliance with OELs and action levels could be determined for most sample locations by measuring only the field strengths for the predominant frequencies. However, this was not the case for sample $121 \mathrm{E}$ (Table 7); on an individual basis, the 5- and 10-MHz E-field strengths were below OELs, but together the E-field strengths exceeded OELs (i.e., ratio to OELs $\geq 1$ ). Thus, it was important to consider multiple frequencies in determining compliance.

\section{CONCLUSIONS}

The research institution's laboratories and atomic time radio stations contained relevant sources of EMF radiation. Static EMF B-fields measured near the superconducting magnet exceeded the ACGIH TLV ceiling limit for medical device wearers. RF E-field strengths measured near the interoperability communications laboratory roof-mounted antennas and HF radio station antennas exceeded the most conservative OELs. RF E-field strengths measured near the LF radio station antennas exceeded the most conservative action levels. On the basis of these results, the research institution should implement a comprehensive EMF safety program.

On the basis of our findings, we recommend the actions listed below to create a safer workplace. We encourage the research institution to use a labor-management health and safety committee or working group to discuss the recommendations in this report and develop an action plan. Those involved in the work can best set priorities and assess the feasibility of our recommendations for the specific situation at the research institution. 
1. Develop a comprehensive EMF safety program. While no specific guidelines exist for sub-RF safety programs, IEEE Standard C95.7-2005 provides guidelines for developing an RF safety program. According to our measurements, the interoperability communications laboratory and atomic time radio stations meet the criteria of a category $3 \mathrm{RF}$ safety program.

2. Assign an EMF safety officer to implement and oversee the EMF safety program at the research institution. A deputy EMF safety officer should be assigned to the atomic time radio stations. Each EMF safety officer should maintain a current copy of the written EMF safety program.

3. Maintain an inventory of relevant EMF sources that have the potential to produce field strengths (or other exposure metrics) near or above OELs or action levels. Conduct initial exposure monitoring and additional exposure monitoring when processes are modified or new sources are introduced.

4. Install informative signs in areas where action levels may be exceeded and caution signs in areas where OELs may be exceeded. Floor markings can be used on solid surfaces to indicate areas where OELs may be exceeded. High voltage areas (e.g., LF and HF antennas) can be fenced off to prevent inadvertent electrical shocks.

5. Conduct annual EMF safety awareness training. Employees should be educated on the potential hazards associated with sub-RF and RF exposures and understand the purpose of signage, floor markings, and other safety procedures (e.g., lockout/tagout) designed to prevent overexposures to EMF or electrical shocks.

6. Modify the incident reporting system to include possible EMF overexposure incidents such as medical device interference, reddening of skin, elevated body temperatures, other evidence of burns, or electrical shocks.

7. Audit the EMF safety program annually. This audit should include a review of any EMF overexposure incidents and EMF monitoring data, inspection of existing controls, and a system that allows employees to provide feedback and recommendations to the EMF safety officer. 
ACGIH [2010]. Threshold limit values for chemical substances and physical agents and biological exposure indices. Cincinnati, $\mathrm{OH}$ : American Conference of Governmental Industrial Hygienists.

FCC [1999]. Questions and answers about biological effects and potential hazards of radiofrequency electromagnetic fields. By Cleveland RF, Ulcek JL. Washington D.C.: U.S. Federal Communications Commission (FCC), OET bulletin 56, 4th edition.

ICNIRP [1998]. Guidelines for limiting exposure to time-varying electric, magnetic, and electromagnetic fields (up to $300 \mathrm{GHz}$ ). Oberschleissheim, Germany: International Commission on NonIonizing Radiation Protection (ICNIRP).

ICNIRP [2009]. Guidelines on limits of exposure to static magnetic fields. Oberschleissheim, Germany: International Commission on Non-Ionizing Radiation Protection (ICNIRP).

IEEE [2002]. IEEE standard for safety levels with respect to human exposure to electromagnetic fields, 0 to $3 \mathrm{kHz}$. New York: Institute of Electrical and Electronics Engineers (IEEE). Standard C95.62002.

IEEE [2005a]. IEEE recommended practice for radio frequency safety programs, $3 \mathrm{kHz}$ to $300 \mathrm{GHz}$. New York: Institute of Electrical and Electronics Engineers (IEEE). Standard C95.7-2005.

IEEE [2005b]. IEEE standard for safety levels with respect to human exposure to radio frequency electromagnetic fields, $3 \mathrm{kHz}$ to $300 \mathrm{GHz}$. New York: Institute of Electrical and Electronics Engineers (IEEE). Standard C95.1-2005.

National Institute of Standards and Technology [2010a]. NIST Radio Station WWVB. [http://www.nist.gov/pml/div688/grp40/ wwvb.cfm]. Date accessed: February 2011.

National Institute of Standards and Technology [2010b]. Radio Station WWV. [http://www.nist.gov/pml/div688/grp40/wwv. cfm]. Date accessed: February 2011. 


\section{Appendix A: Occupational Exposure Limits and Health Effects}

In evaluating the hazards posed by workplace exposures, NIOSH investigators use both mandatory (legally enforceable) and recommended OELs for chemical, physical, and biological agents as a guide for making recommendations. OELs have been developed by Federal agencies and safety and health organizations to prevent the occurrence of adverse health effects from workplace exposures. Generally, OELs suggest levels of exposure that most employees may be exposed up to 10 hours per day, 40 hours per week for a working lifetime without experiencing adverse health effects. However, not all employees will be protected from adverse health effects even if their exposures are maintained below these levels. A small percentage may experience adverse health effects because of individual susceptibility, a preexisting medical condition, and/ or a hypersensitivity (allergy). In addition, some hazardous substances may act in combination with other workplace exposures, the general environment, or with medications or personal habits of the employee to produce health effects even if the occupational exposures are controlled at the level set by the exposure limit. Also, some substances can be absorbed by direct contact with the skin and mucous membranes in addition to being inhaled, which contributes to the individual's overall exposure.

Most OELs are expressed as a TWA exposure. A TWA refers to the average exposure during a normal 8 to 10-hour workday. Some chemical substances and physical agents have recommended STEL or ceiling values where health effects are caused by exposures over a short period. Unless otherwise noted, the STEL is a 15-minute TWA exposure that should not be exceeded at any time during a workday, and the ceiling limit is an exposure that should not be exceeded at any time.

In the United States, OELs have been established by Federal agencies, professional organizations, state and local governments, and other entities. Some OELs are legally enforceable limits, while others are recommendations. The U.S. Department of Labor OSHA PELs (29 CFR 1910 [general industry]; 29 CFR 1926 [construction industry]; and 29 CFR 1917 [maritime industry]) are legal limits enforceable in workplaces covered under the Occupational Safety and Health Act. NIOSH RELs are recommendations based on a critical review of the scientific and technical information available on a given hazard and the adequacy of methods to identify and control the hazard. NIOSH RELs can be found in the NIOSH Pocket Guide to Chemical Hazards [NIOSH 2005]. NIOSH also recommends different types of risk management practices (e.g., engineering controls, safe work practices, employee education/training, personal protective equipment, and exposure and medical monitoring) to minimize the risk of exposure and adverse health effects from these hazards. Other OELs that are commonly used and cited in the United States include the TLVs recommended by ACGIH, a professional organization, and the WEELs recommended by the American Industrial Hygiene Association, another professional organization. The TLVs and WEELs are developed by committee members of these associations from a review of the published, peer-reviewed literature. They are not consensus standards. ACGIH TLVs are considered voluntary exposure guidelines for use by industrial hygienists and others trained in this discipline "to assist in the control of health hazards" [ACGIH 2010]. WEELs have been established for some chemicals "when no other legal or authoritative limits exist" [AIHA 2010].

Outside the United States, OELs have been established by various agencies and organizations and include both legal and recommended limits. Since 2006, the Berufsgenossenschaftliches Institut für Arbeitsschutz (German Institute for Occupational Safety and Health) has maintained a database of international 


\section{Appendix A: Occupational Exposure Limits and Health Effects (CONTINUED)}

OELs from European Union member states, Canada (Québec), Japan, Switzerland, and the United States available at http://www.dguv.de/bgia/en/gestis/limit values/index.jsp. The database contains international limits for over 1250 hazardous substances and is updated annually.

Employers should understand that not all hazardous chemicals have specific OSHA PELs, and for some agents the legally enforceable and recommended limits may not reflect current health-based information. However, an employer is still required by OSHA to protect its employees from hazards even in the absence of a specific OSHA PEL. OSHA requires an employer to furnish employees a place of employment free from recognized hazards that cause or are likely to cause death or serious physical harm [Occupational Safety and Health Act of 1970 (Public Law 91-596, sec. 5(a)(1))]. Thus, NIOSH investigators encourage employers to make use of other OELs when making risk assessment and risk management decisions to best protect the health of their employees. NIOSH investigators also encourage the use of the traditional hierarchy of controls approach to eliminate or minimize identified workplace hazards. This includes, in order of preference, the use of: (1) substitution or elimination of the hazardous agent, (2) engineering controls (e.g., local exhaust ventilation, process enclosure, dilution ventilation), (3) administrative controls (e.g., limiting time of exposure, employee training, work practice changes, medical surveillance), and (4) personal protective equipment (e.g., respiratory protection, gloves, eye protection, hearing protection). Control banding, a qualitative risk assessment and risk management tool, is a complementary approach to protecting employee health that focuses resources on exposure controls by describing how a risk needs to be managed. Information on control banding is available at http://www.cdc.gov/niosh/topics/ ctrlbanding/. This approach can be applied in situations where OELs have not been established or can be used to supplement the OELs, when available.

\section{Static EMF OELs}

The superconducting magnet and magnetic annealer produced static B-fields. Table 1 (on page 5) presents the OELs (ceiling limits) for static B-fields. The OELs we referenced are ICNIRP occupational limits of exposure [ICNIRP 2009], IEEE MPEs for the controlled environment [IEEE 2002], and ACGIH TLVs [ACGIH 2010]. The most conservative OELs were used for making decisions regarding the implementation of EMF safety program elements.

The ICNIRP occupational limits of exposure for static EMF are intended to prevent vertigo, nausea, and other sensations [ICNIRP 2009]. Because these are acute effects, a ceiling limit was specified. The IEEE MPEs $(0-3 \mathrm{kHz})$ for the controlled environment are based on avoidance of the following shortterm reactions: aversive or painful stimulation of sensory or motor neurons, muscle excitation that may lead to injury while performing potentially hazardous activities, excitation of neurons or direct alteration of synaptic activity within the brain, cardiac excitation, and adverse effects associated with induced potentials or forces on rapidly moving charges within the body, such as blood flow [IEEE 2002]. For frequencies below $0.1 \mathrm{~Hz}$, a maximum averaging time of 10 seconds is considered adequate [IEEE 2002]; thus, in practice the IEEE MPE for static EMF may be considered a ceiling limit. The ACGIH TLV for static magnetic fields is based primarily on electrical potentials that are magnetically induced in the 


\section{Appendix A: Occupational Exposure Limits and Health Effects (CONTINUED)}

major arteries of the central circulatory system. The body extremities contain smaller blood vessels and experience smaller induced electrical potentials in strong magnetic fields than do major arteries; hence, the higher ceiling limit for the limbs [ACGIH 2001].

\section{RF OELs and Action Levels}

The interoperability communications laboratory transmitted VHF $(160-170 \mathrm{MHz})$ and UHF (410-420 $\mathrm{MHz})$ signals, while the atomic time radio stations transmitted LF $(60 \mathrm{kHz})$ and $\mathrm{HF}(2.5-20 \mathrm{MHz})$ signals. Table 2 (on page 6) presents the OELs and action levels for VHF and UHF E-field strengths. Tables 3 and 4 (on page 8) present the OELs and action levels for LF and HF E- and H-field strengths. The OELs we referenced are ICNIRP reference levels for occupational exposures [ICNIRP 1998], IEEE MPEs for the upper tier (people in controlled environments) [IEEE 2005b], ACGIH TLVs [ACGIH 2010], and FCC limits for occupational/controlled exposure [FCC 1999]. According to IEEE Standard C95.7, action levels are any of the following criteria: the lower tier limits of IEEE Standard C95.1, the general public guidelines of ICNIRP, 1/5 of the ACGIH TLVs, and the general public/uncontrolled exposure limits of the U.S. FCC [IEEE 2005a]. For this evaluation, all were used as action levels. The most conservative OELs and action levels were used for making decisions regarding the implementation of EMF safety program elements.

The ICNIRP reference levels for time-varying EMF (up to $300 \mathrm{~Hz}$ ) are based on short-term, immediate health effects such as stimulation of peripheral nerves and muscles, shocks and burns caused by touching conducting objects, and elevated tissue temperatures resulting from absorption of energy during exposure to EMF [ICNIRP 1998]. The IEEE MPEs for RF radiation $(3 \mathrm{kHz}$ to $300 \mathrm{GHz})$ are intended to minimize aversive or painful electrostimulation in the frequency range of $3 \mathrm{kHz}$ to $5 \mathrm{MHz}$ and to protect against adverse heating in the frequency range of $100 \mathrm{kHz}$ to $300 \mathrm{GHz}$. In the transition region of $100 \mathrm{kHz}$ to $5 \mathrm{MHz}$, the MPEs are intended to protect against both electrostimulation and thermal effects [IEEE 2005b]. The FCC MPEs are intended to prevent similar health effects [FCC 1999]. The ACGIH TLVs for $\mathrm{RF}$ and microwave radiation are based upon the belief that the primary adverse physiological effects of electromagnetic energy in this wavelength and frequency region are thermal [ACGIH 2006]. Two areas of the body, the eyes and the testes, are known to be particularly vulnerable to heating by RF energy because of the relative lack of available blood flow to dissipate the excessive heat load. Intense RF exposures to the eyes of animals have been shown to cause cataracts. Intense RF exposures to the testes of animals have been shown to cause temporary sterility [FCC 1999].

\section{References}

ACGIH [2001]. Static magnetic fields. In: Documentation of the threshold limit values and biological exposure indices. Cincinnati, $\mathrm{OH}$ : American Conference of Governmental Industrial Hygienists (ACGIH). 


\section{Appendix A: Occupational Exposure Limits and Health Effects (CONTINUED)}

ACGIH [2006]. Radiofrequency and microwave radiation In: Documentation of the threshold limit values and biological exposure indices. Cincinnati, $\mathrm{OH}$ : American Conference of Governmental Industrial Hygienists (ACGIH).

ACGIH [2010]. Threshold limit values for chemical substances and physical agents and biological exposure indices. Cincinnati, OH: American Conference of Governmental Industrial Hygienists.

AIHA [2010]. AIHA 2010 Emergency response planning guidelines (ERPG) \& workplace environmental exposure levels (WEEL) handbook. Fairfax, VA: American Industrial Hygiene Association.

CFR. Code of Federal Regulations. Washington, DC: U.S. Government Printing Office, Office of the Federal Register.

FCC [1999]. Questions and answers about biological effects and potential hazards of radiofrequency electromagnetic fields. By Cleveland RF, Ulcek JL. Washington D.C.: U.S. Federal Communications Commission (FCC), OET bulletin 56, 4th edition.

ICNIRP [1998]. Guidelines for limiting exposure to time-varying electric, magnetic, and electromagnetic fields (up to $300 \mathrm{GHz}$ ). Oberschleissheim, Germany: International Commission on Non-Ionizing Radiation Protection (ICNIRP).

ICNIRP [2009]. Guidelines on limits of exposure to static magnetic fields. Oberschleissheim, Germany: International Commission on Non-Ionizing Radiation Protection (ICNIRP).

IEEE [2002]. IEEE standard for safety levels with respect to human exposure to electromagnetic fields, 0 to $3 \mathrm{kHz}$. New York: Institute of Electrical and Electronics Engineers (IEEE). Standard C95.6-2002.

IEEE [2005a]. IEEE recommended practice for radio frequency safety programs, $3 \mathrm{kHz}$ to $300 \mathrm{GHz}$. New York: Institute of Electrical and Electronics Engineers (IEEE). Standard C95.7-2005.

IEEE [2005b]. IEEE standard for safety levels with respect to human exposure to radio frequency electromagnetic fields, $3 \mathrm{kHz}$ to $300 \mathrm{GHz}$. New York: Institute of Electrical and Electronics Engineers (IEEE). Standard C95.1-2005.

NIOSH [2005]. NIOSH pocket guide to chemical hazards. Cincinnati, OH: U.S. Department of Health and Human Services, Centers for Disease Control and Prevention, National Institute for Occupational Safety and Health, DHHS (NIOSH) Publication No. 2005-149. [http://www.cdc.gov/niosh/npg/]. Date accessed: February 2011. 

Radio Stations

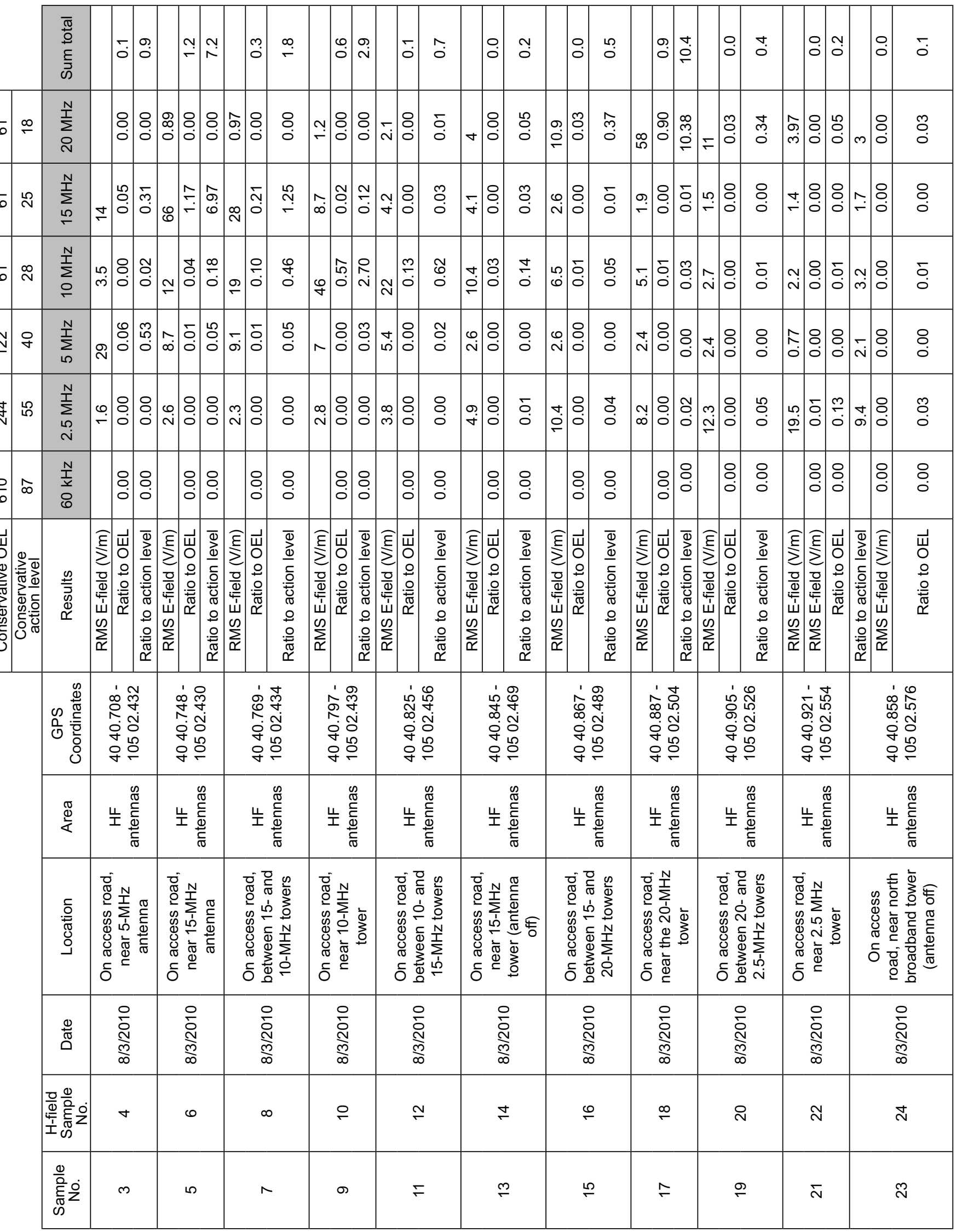


Appendix B: E-field Strenghts Measured at the Atomic Time Radio Stations (COntinued)

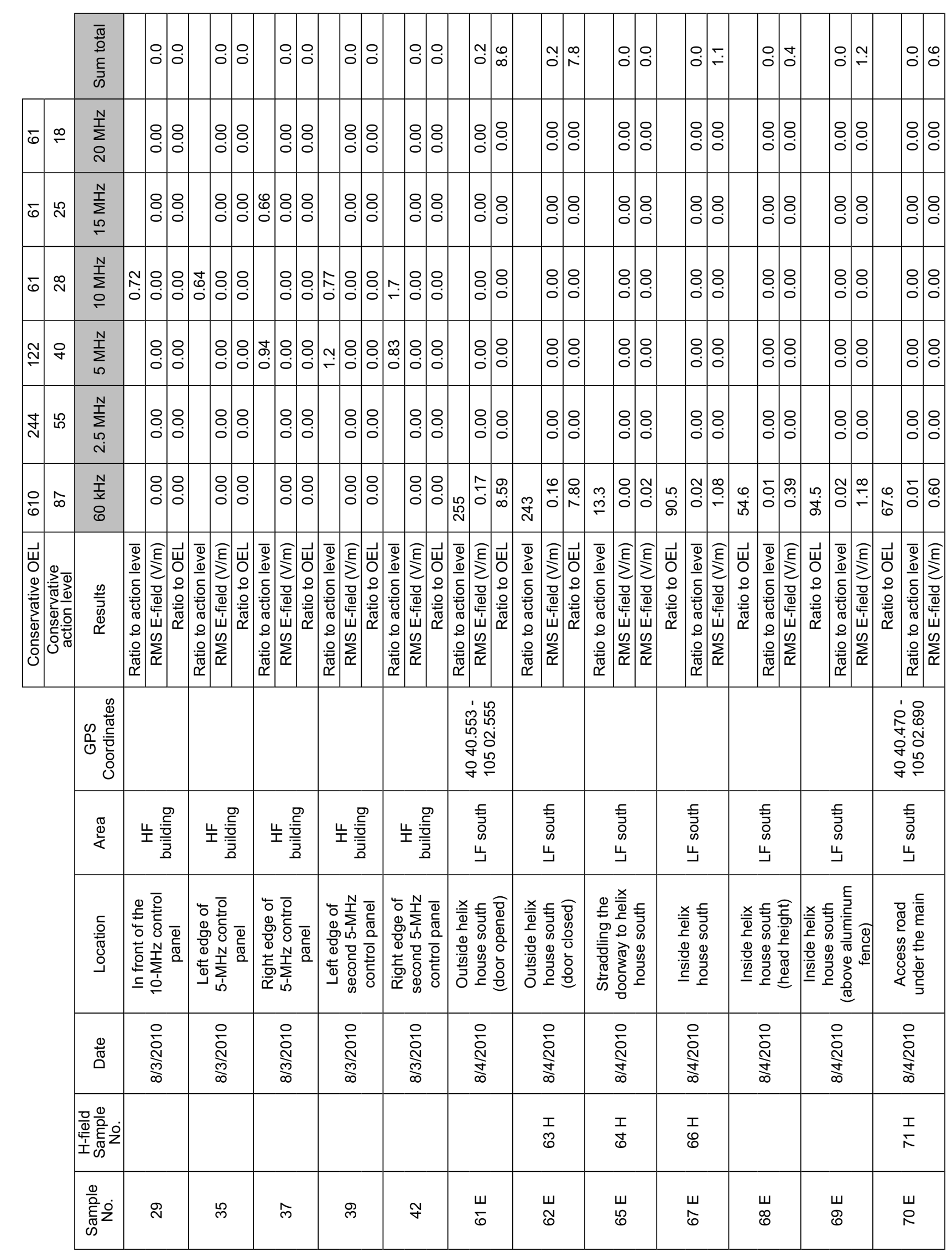


Appendix B: E-field Strenghts Measured at the Atomic Time RADio StATIONS (CONTINUED)

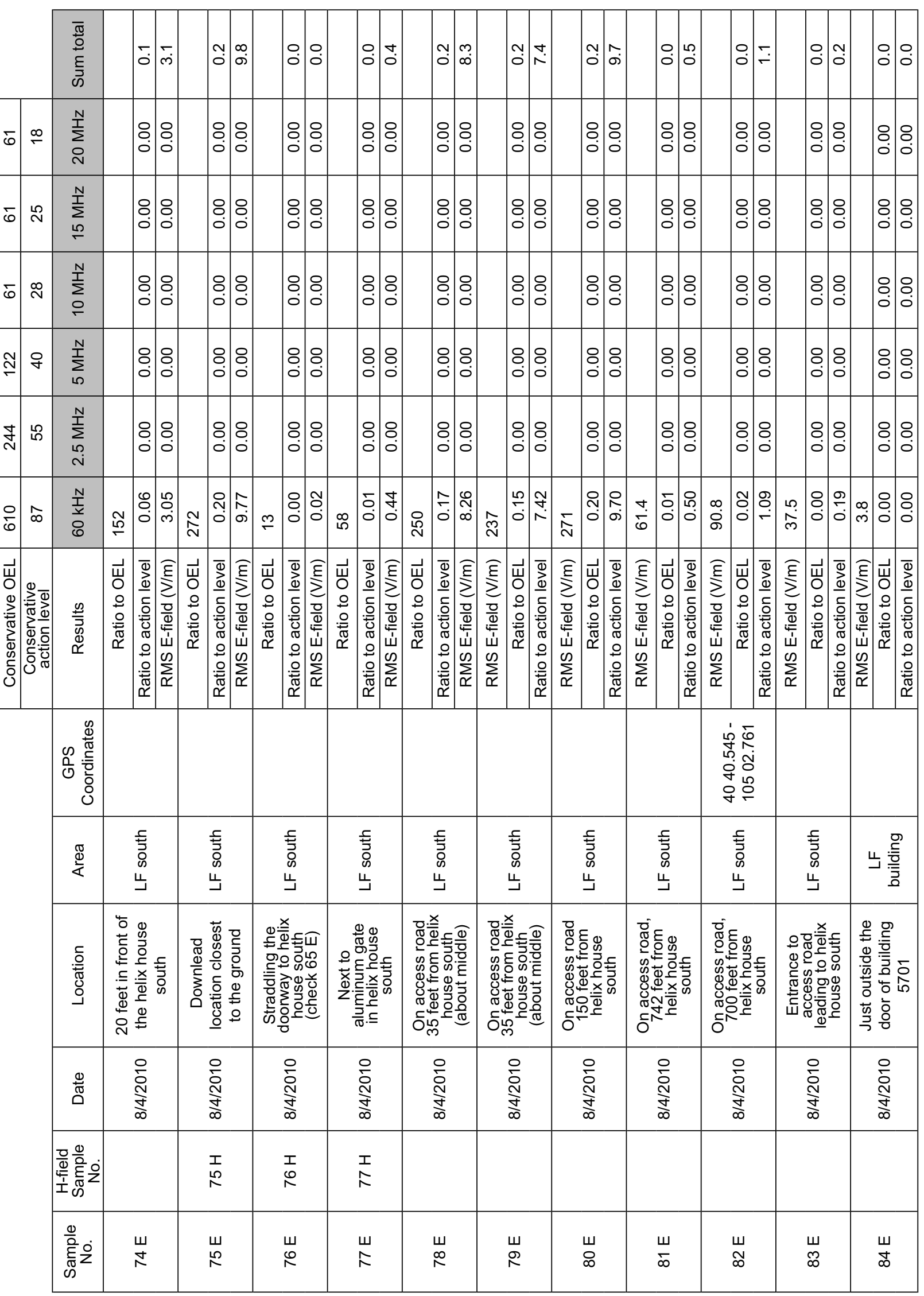


Appendix B: E-field Strenghts Measured at the Atomic Time Radio Stations (CONTINUED)

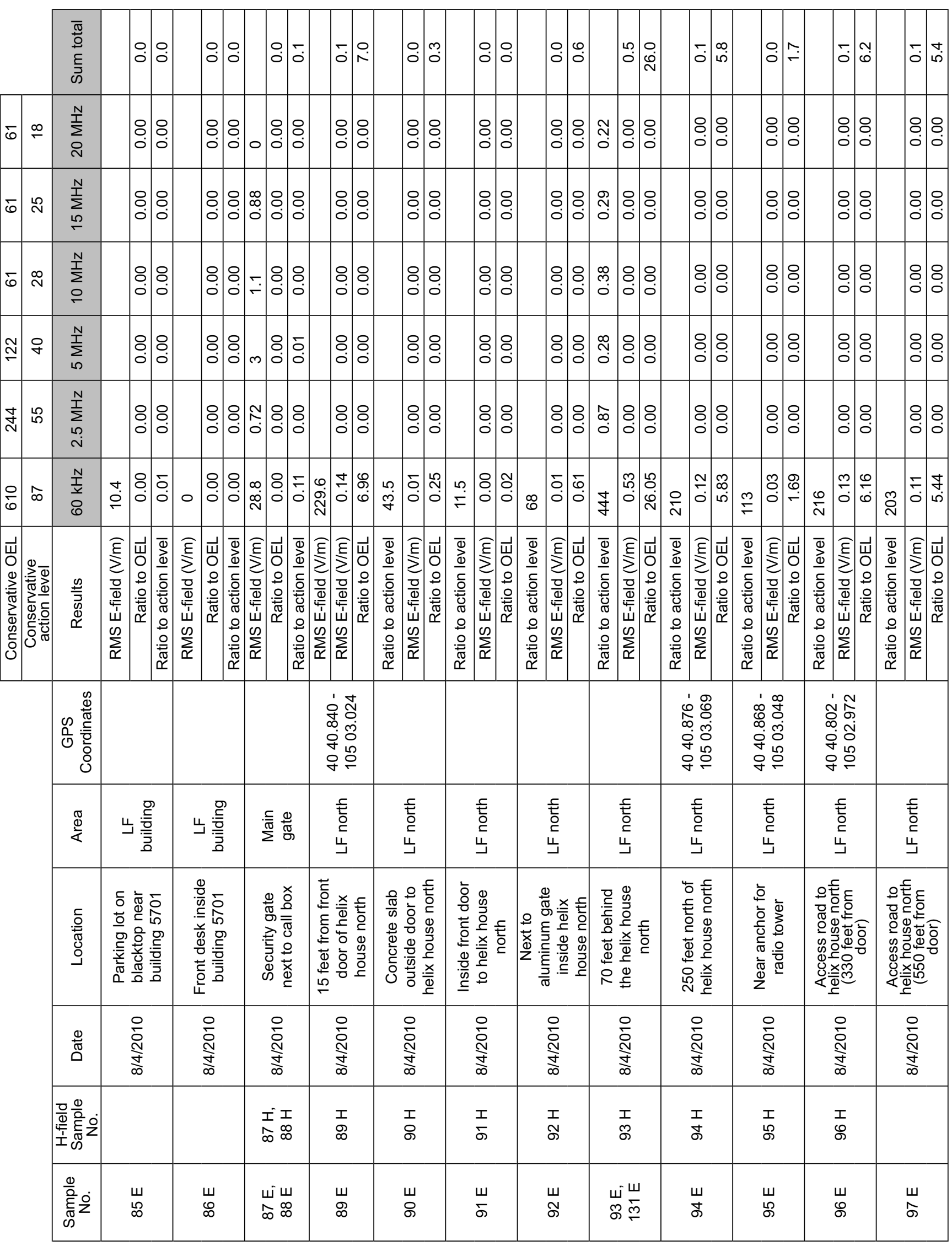


Appendix B: E-field Strenghts Measured at the Atomic Time RADio Stations (CONTINUED)

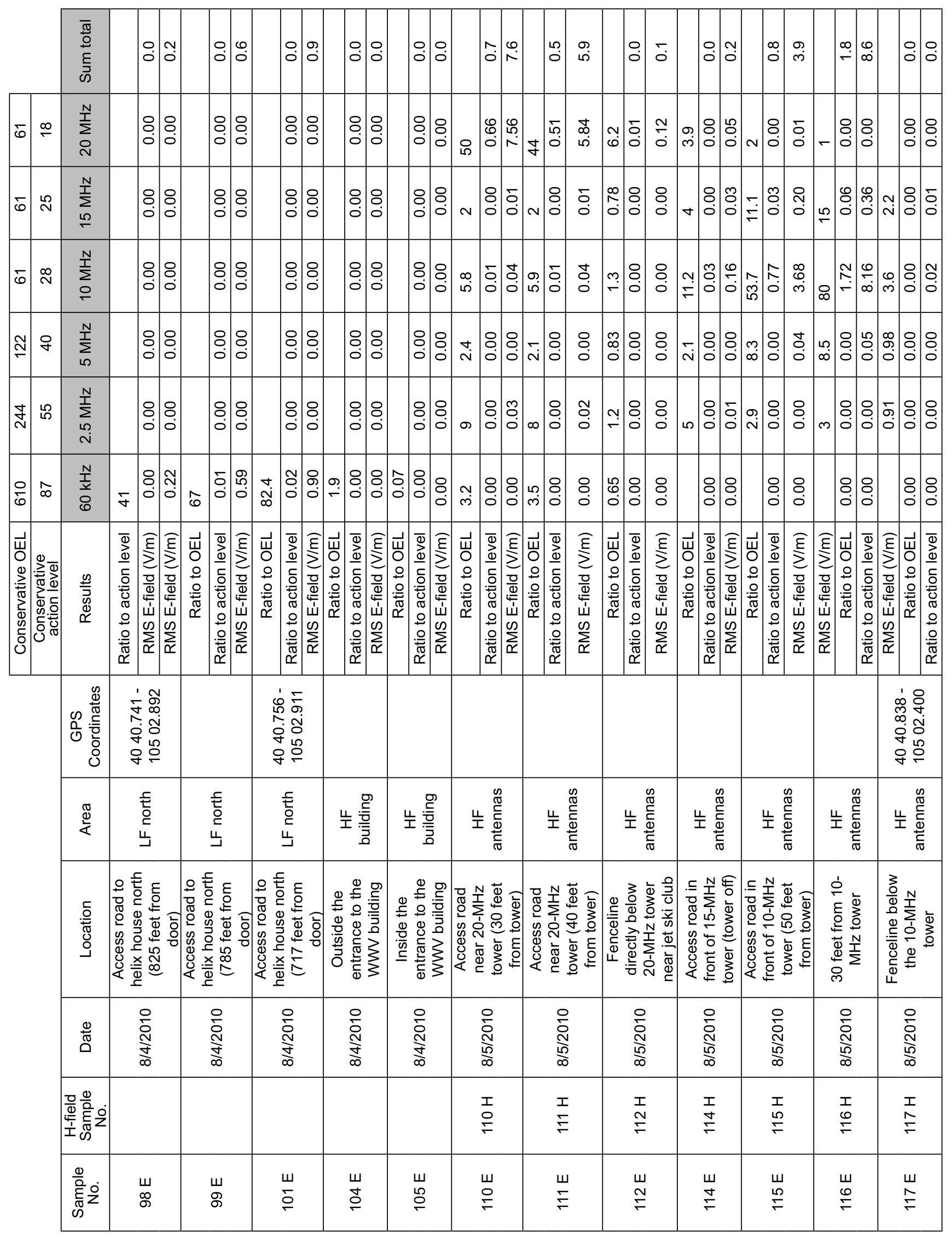


Appendix B: E-field Strenghts Measured at the Atomic Time RAdio Stations (CONTINUED)

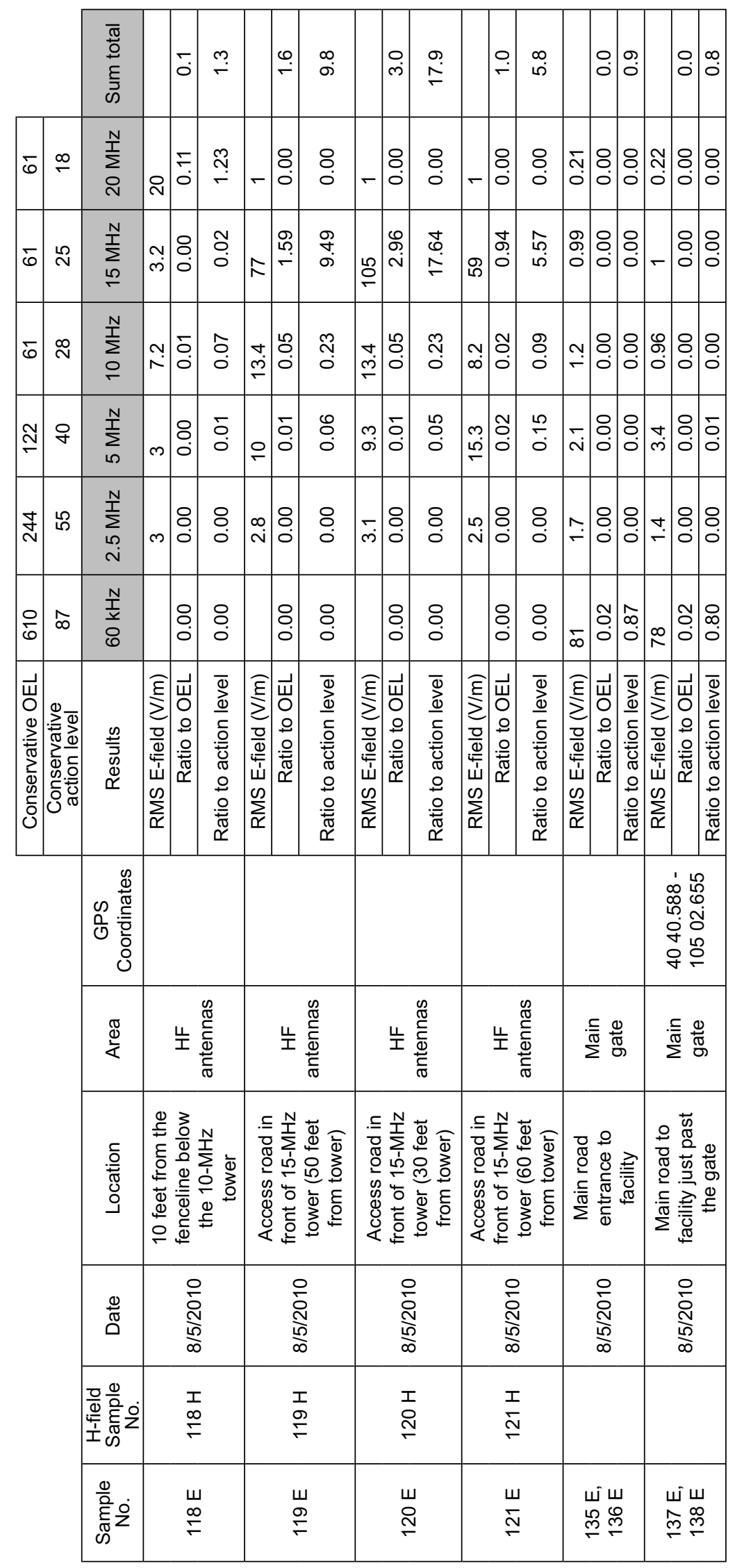




\section{Appendix C: H-field Strengths Measured at the Atomic Time Radio Satatons}

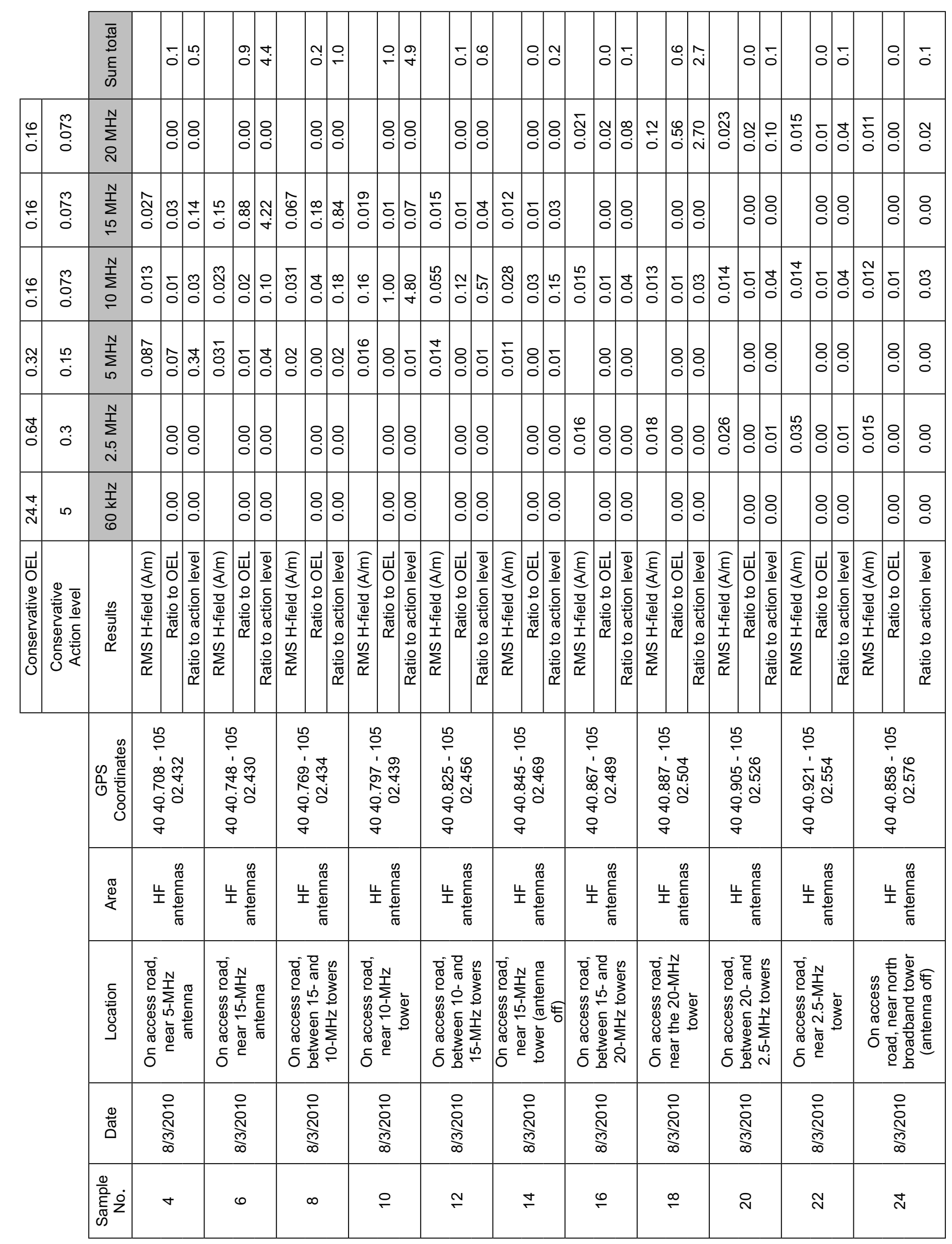


Appendix C: H-field Strenghts Measured at the Atomic Time RADIO SATATONS (CONTINUED)

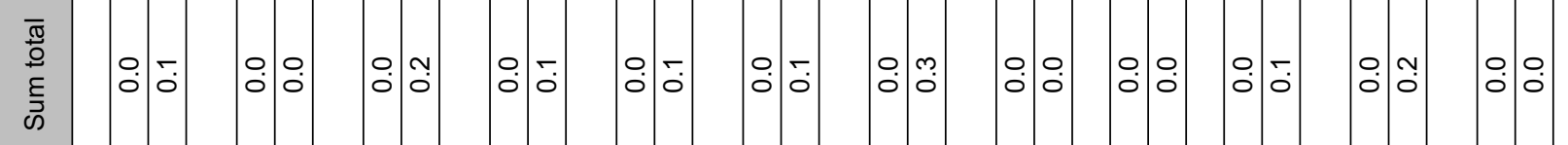

\begin{tabular}{|c|c|c|c|c|c|c|c|c|c|c|c|c|c|}
\hline $\begin{array}{lll}0 & 0 \\
0 & 0\end{array}$ & 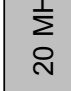 & & $\begin{array}{lll}8 & 0 \\
0 & 0 \\
0\end{array}$ & \begin{tabular}{l|l|}
0 \\
0 \\
0
\end{tabular} & 잉: & O: & \begin{tabular}{ll|}
0 & 0 \\
0 & 0 \\
0 & 0
\end{tabular} & \begin{tabular}{l|l|}
0 & 0 \\
0 & 0 \\
0
\end{tabular} & \begin{tabular}{l|l|} 
& 0 \\
0 & 0 \\
0
\end{tabular} & : & : & : & : \\
\hline
\end{tabular}

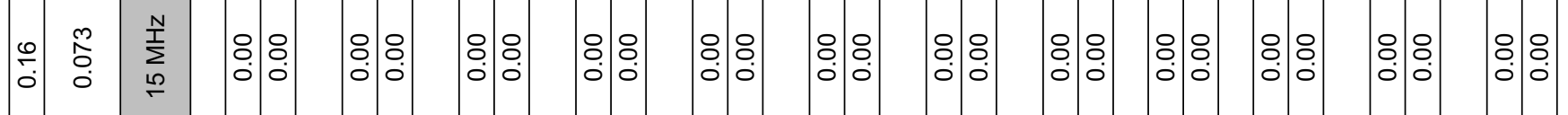

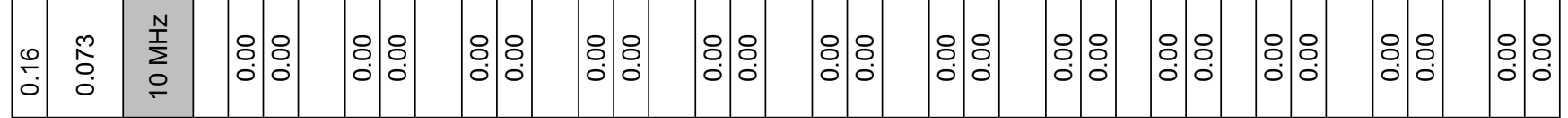

留

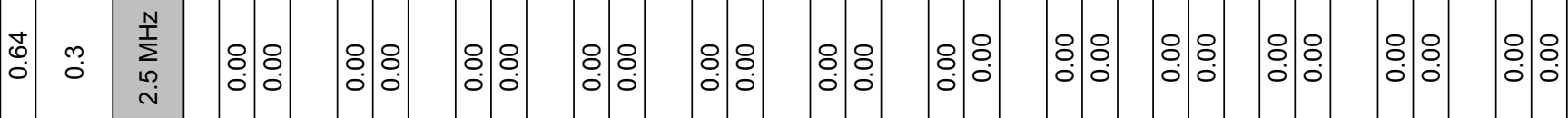

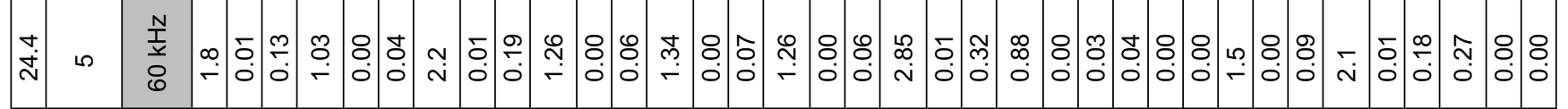

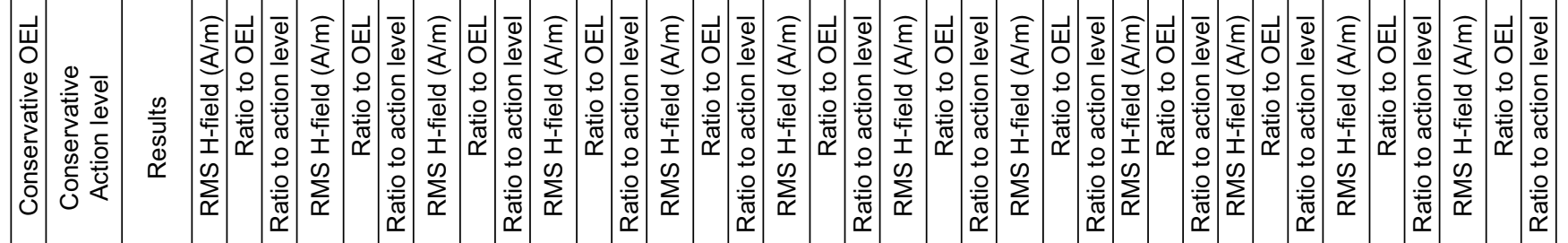

\begin{tabular}{|c|c|c|c|c|c|c|c|c|c|c|c|c|}
\hline $\begin{array}{r}\frac{9}{4} \\
0 \\
0 \\
0 \\
0 \\
0 \\
\frac{0}{0} \\
0 \\
0\end{array}$ & & & & 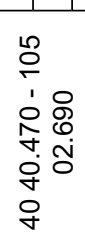 & & & & & & 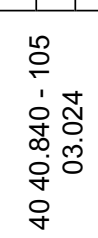 & & \\
\hline 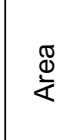 & 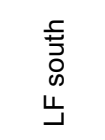 & 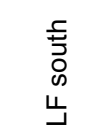 & 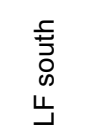 & 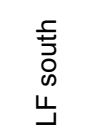 & 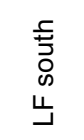 & 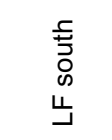 & $\begin{array}{l}\text { F } \\
\overline{0} \\
0 \\
\sqcup \\
\sqsupset\end{array}$ & 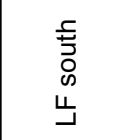 & 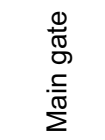 & 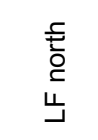 & $\begin{array}{l}\bar{E} \\
\bar{े} \\
\bar{\Xi} \\
\sqcup\end{array}$ & 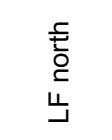 \\
\hline 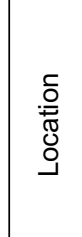 & 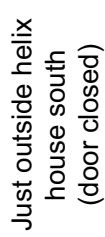 & 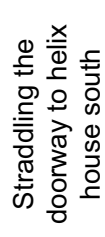 & 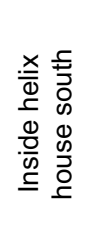 & 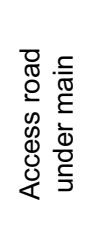 & 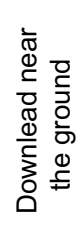 & 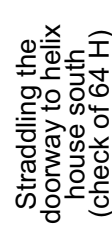 & 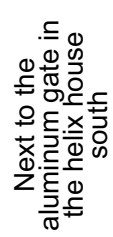 & 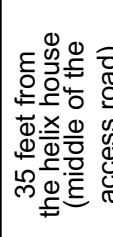 & 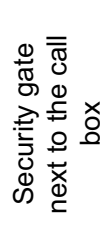 & 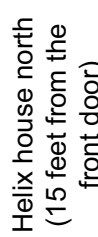 & 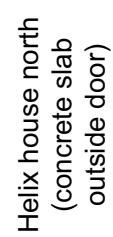 & 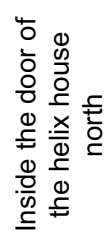 \\
\hline$\frac{0}{\pi}$ & $\begin{array}{l}\frac{0}{2} \\
\frac{N}{\infty} \\
\infty\end{array}$ & 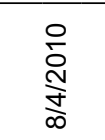 & 을 & 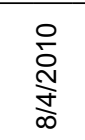 & 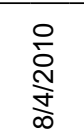 & $\frac{\text { 음 }}{\stackrel{\text { \} }{\infty}}} &{\frac{\substack{\mathfrak{N} \\
\frac{\text { J }}{\infty}}}{}} &{\begin{array}{l}\text { 을 } \\
\frac{N}{\infty} \\
\frac{5}{\infty}\end{array}} &{\text { 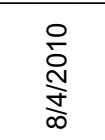 }} &{\frac{\substack{\frac{N}{5} \\
\frac{j}{\infty}}}{}} &{\frac{\stackrel{0}{\grave{N}}}{\frac{1}{\infty}}} &{\frac{\substack{\frac{N}{5} \\
\frac{j}{\infty}}}{}} \\
{\hline \text { 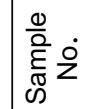 }} &{\begin{array}{l}I \\
\mathbb{0}\end{array}} &{\begin{array}{l}I \\
\text { I }\end{array}} &{\begin{array}{l}I \\
8\end{array}} &{\frac{I}{r}} &{\begin{array}{l}I \\
\stackrel{I}{R}\end{array}} &{\begin{array}{l}I \\
\stackrel{Q}{R}\end{array}} &{\begin{array}{l}I \\
\text { N }\end{array}} &{\text { 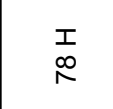 }} &{\begin{array}{l}I^{I} \\
\hat{D} \infty \\
\infty\end{array}} &{\begin{array}{l}\text { I } \\
\infty\end{array}} &{\frac{5}{8}} &{\frac{I}{\sigma}} \\
$\hline
\end{tabular}


Appendix C: H-field Strenghts Measured at the Atomic Time Radio SATATONS (CONTINUED)

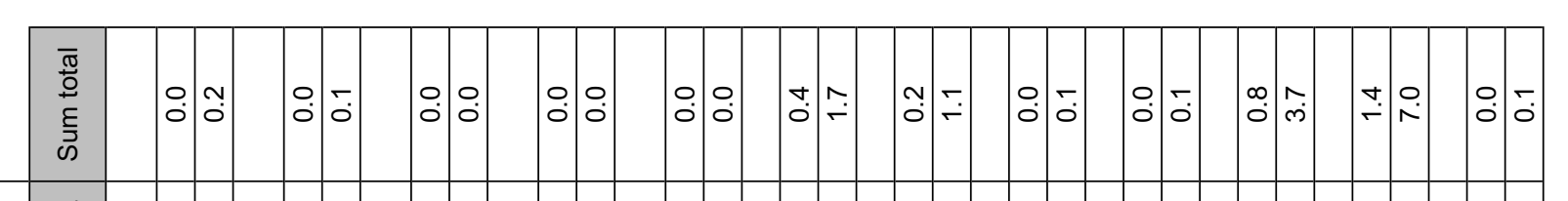

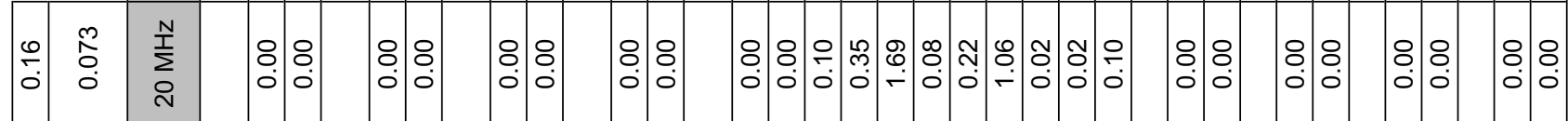

옹ํำ

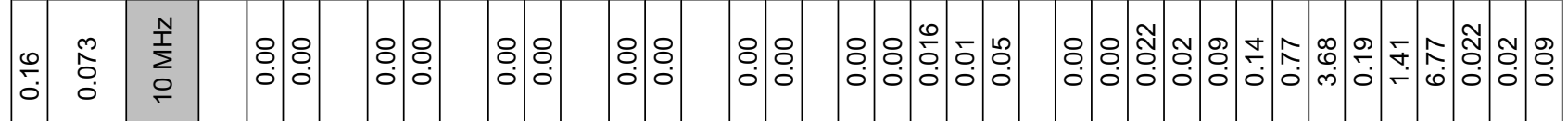

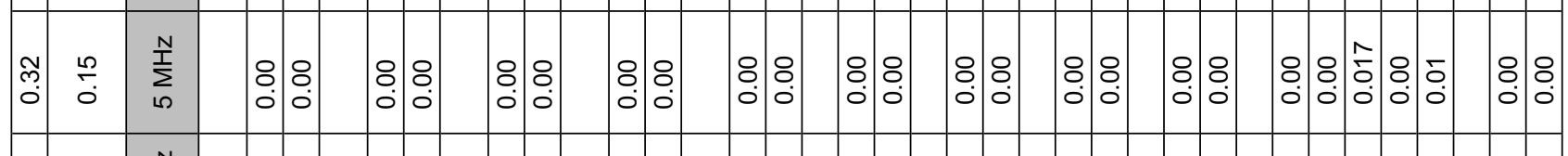

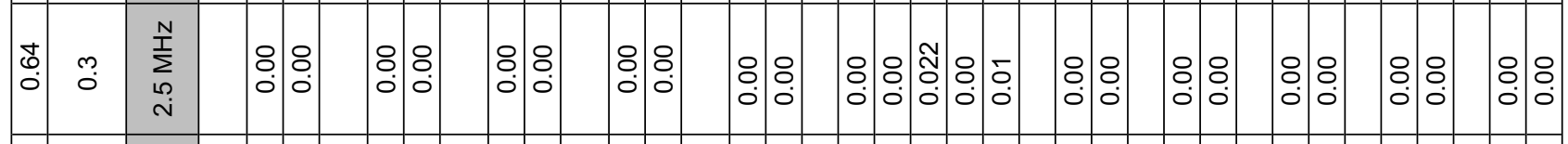

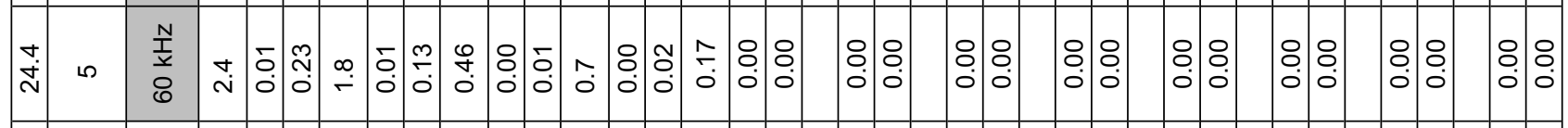

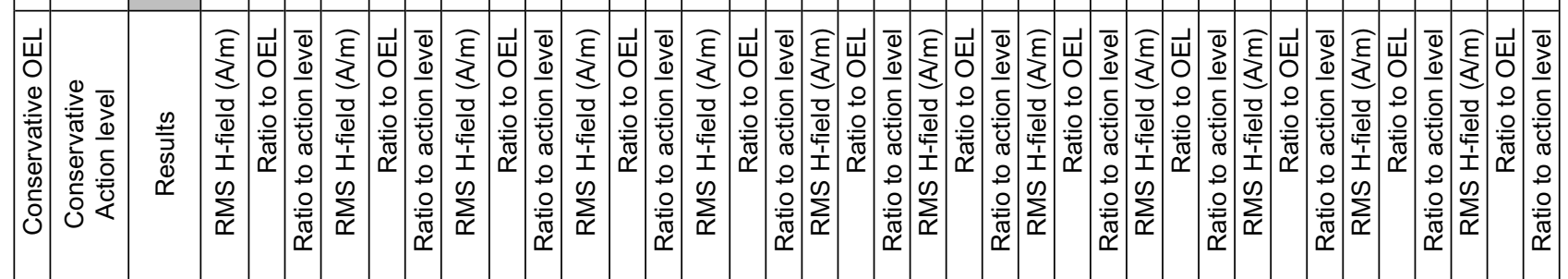

\begin{tabular}{|c|c|c|c|c|c|c|c|c|c|c|c|c|}
\hline 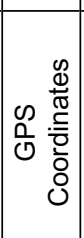 & & & 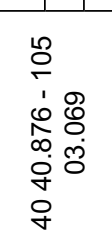 & 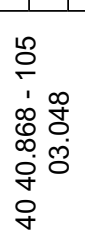 & 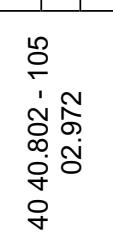 & & & & & & & 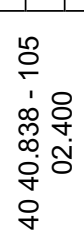 \\
\hline 蛋 & 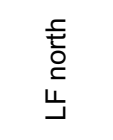 & $\begin{array}{l}\frac{c}{ \pm} \\
\stackrel{0}{0} \\
\sqcup\end{array}$ & 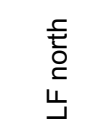 & 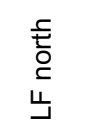 & 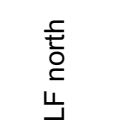 & 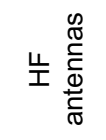 & 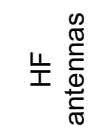 & 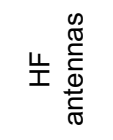 & 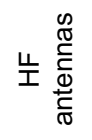 & 岌 & 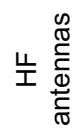 & 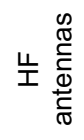 \\
\hline 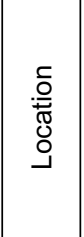 & 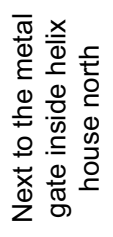 & 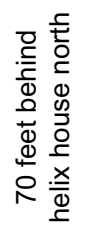 & 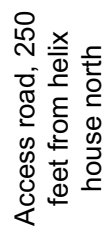 & 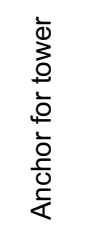 & 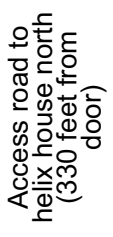 & 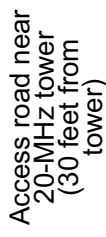 & 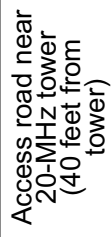 & 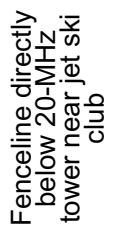 & 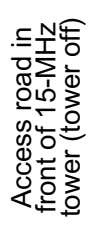 & 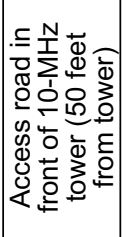 & 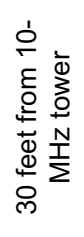 & 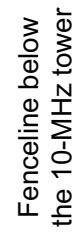 \\
\hline$\frac{⿱}{\pi}$ & 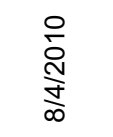 & $\frac{\circ}{\stackrel{ }{\grave{d}}}$ & 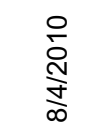 & $\frac{O}{\stackrel{N}{\frac{1}{\infty}}}$ & 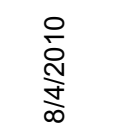 & $\begin{array}{l}\frac{0}{\grave{2}} \\
\frac{N}{\grave{1}} \\
\frac{1}{\infty}\end{array}$ & 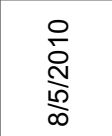 & $\begin{array}{l}\frac{0}{2} \\
\stackrel{N}{\frac{N}{\infty}}\end{array}$ & 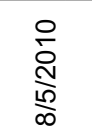 & $\begin{array}{l}\text { 울 } \\
\stackrel{N}{\frac{N}{\infty}}\end{array}$ & $\begin{array}{l}\circ \\
\stackrel{\circ}{N} \\
\frac{N}{\infty}\end{array}$ & $\begin{array}{l}\frac{0}{\mathrm{~N}} \\
\frac{N}{\infty} \\
\frac{0}{\infty}\end{array}$ \\
\hline 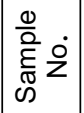 & $\begin{array}{l}I \\
\mathcal{N}\end{array}$ & $\begin{array}{l}I \\
\text { ऽ }\end{array}$ & $\begin{array}{l}I \\
\text { I }\end{array}$ & $\begin{array}{l}I \\
\stackrel{\leftrightarrow}{\circ}\end{array}$ & $\begin{array}{l}I \\
\&\end{array}$ & $\begin{array}{l}\text { I } \\
\stackrel{\rho}{ }\end{array}$ & $\frac{I}{\Sigma}$ & $\stackrel{I}{\underset{I}{F}}$ & 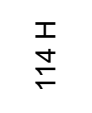 & $\underset{\stackrel{I}{L}}{\stackrel{2}{\digamma}}$ & $\begin{array}{l}I \\
\stackrel{I}{\rightleftharpoons}\end{array}$ & $\begin{array}{l}\text { I } \\
\stackrel{F}{E}\end{array}$ \\
\hline
\end{tabular}


Appendix C: H-field Strenghts Measured at the Atomic Time Radio SATATONS (CONTINUED)

\begin{tabular}{|c|c|c|c|c|c|c|c|c|c|}
\hline & & 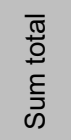 & $\stackrel{8}{\circ}$ & $\mid \begin{array}{c}\text { ô } \\
\text { | }\end{array}$ & 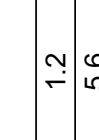 & : & $\hat{N} \mid \stackrel{\infty}{\stackrel{N}{N}}$ & & 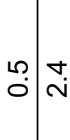 \\
\hline $\begin{array}{l}0 \\
0 \\
0\end{array}$ & 芯 & $\begin{array}{l}\sum_{D}^{N} \\
\stackrel{N}{I}\end{array}$ & $\begin{array}{l}8 \\
0\end{array}$ & $\begin{array}{l}0 \\
0 \\
0\end{array}$ & : & $\begin{array}{l}8 \\
0 \\
0\end{array}$ & 8: & & $\begin{array}{l}8 \\
0 \\
\end{array}$ \\
\hline $\begin{array}{l}0 \\
\dot{0}\end{array}$ & 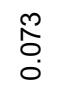 & $\sum_{\stackrel{L}{T}}^{N}$ & : & : & 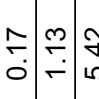 & \begin{tabular}{c}
\multirow{2}{*}{} \\
\multirow{2}{*}{}
\end{tabular} & 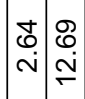 & $\begin{array}{l}b \\
j\end{array}$ & \begin{tabular}{l}
\multirow{f}{0}{} \\
$\dot{0}$
\end{tabular} \\
\hline $\begin{array}{l}0 \\
\check{0}\end{array}$ & $\begin{array}{l}\stackrel{M}{0} \\
0 \\
0\end{array}$ & $\begin{array}{l}\text { N } \\
\sum \\
\stackrel{0}{O}\end{array}$ & 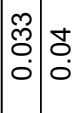 & ని & 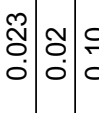 & 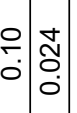 & ס & $=\begin{array}{c}\hat{n} \\
\dot{\delta} \\
0 \\
0\end{array}$ & 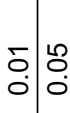 \\
\hline $\begin{array}{c}\tilde{N} \\
0 \\
0\end{array}$ & $\stackrel{\frac{L}{2}}{\circ}$ & $\sum_{i n}^{N}$ & \&. & 吕 & 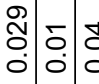 & $\begin{array}{c}0 \\
\vdots \\
0\end{array}$ & & 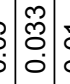 & 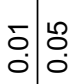 \\
\hline $\begin{array}{l}\mathbf{U} \\
\vdots \\
0\end{array}$ & $\stackrel{m}{0}$ & $\underset{\substack{\infty \\
N}}{N}$ & : & : & : & $\begin{array}{l}8 \\
0 \\
0\end{array}$ & 잉유 & & \begin{tabular}{l}
8 \\
\hdashline \\
0
\end{tabular} \\
\hline$\dot{\Delta}$ & ம & $\begin{array}{l}\frac{N}{T} \\
\frac{1}{8}\end{array}$ & ¿ & 足 & : & $\begin{array}{l}8 \\
0 \\
0\end{array}$ & : & & : \\
\hline 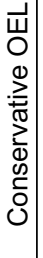 & 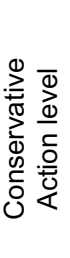 & 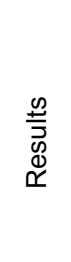 & 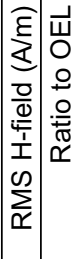 & 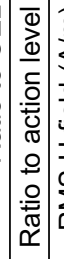 & 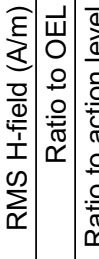 & 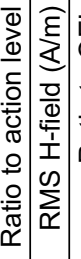 & 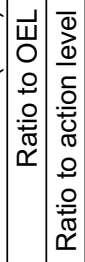 & 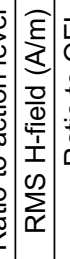 & 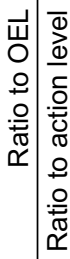 \\
\hline & & 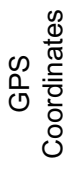 & & & & & & & \\
\hline & & $\stackrel{\mathbb{\Phi}}{\stackrel{\mathbb{\alpha}}{<}}$ & 㞬 & & 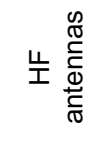 & & 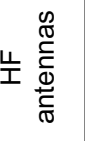 & & L \\
\hline & & 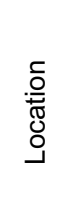 & 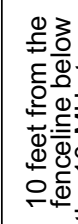 & & 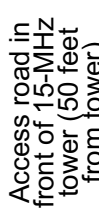 & 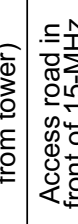 & 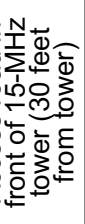 & & 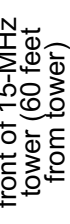 \\
\hline & & 离 & $\frac{}{0}$ & & $\frac{}{\stackrel{0}{N}}$ & & $\frac{\circ}{\stackrel{\circ}{N}}$ & & $\frac{}{\stackrel{0}{N}}$ \\
\hline & & 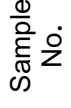 & $\stackrel{\infty}{\leftarrow}$ & & $\begin{array}{l}I \\
\stackrel{9}{E}\end{array}$ & & I & & $\begin{array}{l}I \\
\grave{N}\end{array}$ \\
\hline
\end{tabular}


The Hazard Evaluations and Technical Assistance Branch (HETAB) of the National Institute for Occupational Safety and Health (NIOSH) conducts field investigations of possible health hazards in the workplace. These investigations are conducted under the authority of Section 20(a)(6) of the Occupational Safety and Health Act of 1970, 29 U.S.C. 669(a)(6) which authorizes the Secretary of Health and Human Services, following a written request from any employer or authorized representative of employees, to determine whether any substance normally found in the place of employment has potentially toxic effects in such concentrations as used or found. HETAB also provides, upon request, technical and consultative assistance to federal, state, and local agencies; labor; industry; and other groups or individuals to control occupational health hazards and to prevent related trauma and disease.

The findings and conclusions in this report are those of the authors and do not necessarily represent the views of NIOSH. Mention of any company or product does not constitute endorsement by NIOSH. In addition, citations to websites external to NIOSH do not constitute NIOSH endorsement of the sponsoring organizations or their programs or products. Furthermore, NIOSH is not responsible for the content of these websites. All Web addresses referenced in this document were accessible as of the publication date.

This report was prepared by Kenneth W. Fent of HETAB, Division of Surveillance, Hazard Evaluations and Field Studies and David Conover, an independent contractor. Industrial hygiene field assistance was provided by James Couch of HETAB. Expertise and field assistance in measuring magnetic fields was provided by Joseph Bowman of the Division of Applied Research and Technology. Health communication assistance was provided by Stefanie Evans of HETAB. Editorial assistance was provided by Ellen Galloway of the Education and Information Division. Desktop publishing was performed by Robin Smith of HETAB.

Copies of this report have been sent to employee and management representatives at the research institution, the Colorado Department of Public Health and Environment, and the Occupational Safety and Health Administration Region 8 Office. This report is not copyrighted and may be freely reproduced. The report may be viewed and printed at http://www.cdc.gov/niosh/ hhe/. Copies may be purchased from the National Technical Information Service at 5825 Port Royal Road, Springfield, Virginia 22161. 
Below is a recommended citation for this report:

NIOSH [2011]. Health hazard evaluation report: evaluation of electromagnetic field

exposures at a research institution's laboratories and atomic time radio stations

- Colorado. By Fent KW and Conover D. Cincinnati, OH: U.S. Department of

Health and Human Services, Centers for Disease Control and Prevention, National

Institute for Occupational Safety and Health, NIOSH HETA No. 2009-0171-3119.

National Institute for Occupational Safety and Health

\section{Delivering on the Nation's promise: Safety and health at work for all people through research and prevention.}

To receive NIOSH documents or information about occupational safety and health topics, contact NIOSH at:

1-800-CDC-INFO (1-800-232-4636)

TTY: 1-888-232-6348

E-mail: cdcinfo@cdc.gov

or visit the NIOSH web site at: www.cdc.gov/niosh.

For a monthly update on news at $\mathrm{NIOSH}$, subscribe to $\mathrm{NIOSH}$ eNews by visiting www.cdc.gov/niosh/eNews. 